\title{
Hakekat, Filsafat dan Sejarah Komunikasi Politik
}

\author{
Mirza Shahreza \\ mirzashahreza@gmail.com
}

\section{A. Hakekat Komunikasi Politik}

Komunikasi politik merupakan gabungan dua disiplin ilmu sosial, yaitu ilmu komunikasi dan politik. Bahkan pendiri (The founding father) yang menjadikan komunikasi sebagai ilmu pengetahuan diantaranya adalah para sarjana politik, seperti Harold D. Lasswell, Wilbur Schramm. Laswell terkenal dengan "laswellian framework" (who, says what, to Whom, with what channel and with what effect) suatu rumus yang sangat penting dan pasti menjadi suatu landasan dalam kajian ilmu komunikasi. Sejak perang dunia pertama dan kedua, salah satu jalan keluar yang ditempuh untuk menyelesaikan ketegangan adalah melalui meja perundingan dan diselesaikan dengan peranan kegiatan diplomasi dan negosiasi untuk mencapai titik win-win Solutions. Dalam proses negosiasi tersebutlah peran kemampuan berkomunikasi diantara kedua pihak yang berseteru sangat berpengaruh dalam rangka menyudahi peperangan dan mempertahankan kepentingan masing-masing pihak. Peristiwa tersebut termasuk momentum yang akhirnya memunculkan disiplin ilmu baru pada saat itu, yaitu ilmu komunikasi.

Menarik waktu lebih awal dari sejarah kehidupan manusia, komunikasi politik dapat tergambarkan dalam peristiwa perseteruan Adam dan Iblis. Pada saat Tuhan (The Communicator) memerintahkan (massage) semua malaikat (Communicant) sujud (patuh) kepada Adam (yang ditunjuk sebagai pemimpin), maka pada saat itu ada suatu perlawanan (ketidakpatuhan kepada Tuhan) yaitu Iblis. ${ }^{1}$ Ketidakpatuhan Iblis tersebut dinyatakan dengan suatu

\footnotetext{
${ }^{1}$ Qs, Al-Baqarah: 2/30: Dan Ingatlah ketika Tuhanmu berfirman kepada para malaikat: "Sesungguhnya Aku hendak menjadikan seorang khalifah di muka bumi". Mereka berkata: "Mengapa Engkau hendak menjadikan (khalifah) di bumi itu orang yang akan membuat kerusakan padanya dan menumpahkan darah, padahal kami senantiasa bertasbih dengan memuji Engkau dan menyucikan Engkau?" Tuhan berfirman: "Sesungguhnya Aku mengetahui apa yang tidak kamu ketahui". Qs, Al-A'raaf,7/11: Sesungguhnya Kami telah menciptakan kamu (Adam), lalu Kami bentuk tubuhmu, kemudian Kami katakan kepada para
} 
argumentasi (feedback) bahwa dia (api) lebih baik dari Adam yang tercipta dari tanah. Ketidakpatuhan Iblis berdampak (effect) diusir atau dikeluarkan dari surga yang merupakan simbol sebuah tempat (kekuasaan). Setelah itu Iblispun bersumpah untuk berupaya menggoda semua anak keturunan Adam di muka bumi. Kekuasaan memang menjadi sesuatu yang diperebutkan, kepentingan untuk berkuasa adalah untuk dapat menerapkan ideologi atau faham yang dimiliki oleh seseorang atau kelompok. Sehingga ini menggambarkan bahwa politik memang sudah ada sejak semua mahluk diciptakan. Dan politik itu akan selalu dikomunikasikan untuk dapat mencapai tujuannya, bisa dengan cara yang baik dan bisa pula dengan cara yang jahat, seperti menghasut, fitnah dan tipu daya.

Selanjutnya di dunia manusia memang mempunyai kecendrungan hidup berkelompok dan menguasai tanah-tanah yang akhirnya menjadi daerah kekuasaan. Manusia berkumpul dengan berbagai kesamaan mulai dari ras, bahasa, dan budaya. Setiap kelompok secara alami akan memunculkan atau mengangkat seorang pemimpin diantara mereka. Kepemimpinan pada zaman dulu cenderung membentuk kerajaan (monarki) yang akhirnya mewariskan kekuasaannya kepada keturunannya. Lama berkuasa turunmenurun mempunyai potensi untuk memunculkan pemimpin yang otoriter dan bahkan menindas rakyatnya. Gaya kepemimpinan yang zalim akan memunculkan akumulasi perlawanan dari rakyatnya sendiri. Maka pergolakan politik akan terjadi di suatu kerajaan atau pemerintahan.

Ketidakstabilan politik akan memunculkan kekacauan yang berdampak terjadinya kerusakan moral dan juga kemiskinan yang akan memunculkan perilaku sosial yang negatif seperti prostitusi, kriminal dan pergaulan bebas. Kondisi seperti ini sudah diceritakan dalam kitab suci dan pasti The Communicator (Tuhan) akan menunjuk seorang agen perubahan (agent of change) melalui perantara malaikat Jibril (Gabriel) yang dinamakan "Nabi" atau pembawa berita (massage) untuk menyadarkan dan mengembalikan kaumnya ke jalan yang lurus dan juga suatu perlawanan terhadap penguasa zalim seperti Fira'aun, Namrud, Herodes dan juga Abu Jahal. Lalu selain nabi ada pembawa pesan (massage) yang bergerak lebih masif yaitu "Rasul" yang berarti utusan. Rasul sebagai sarana (channel) agar pesan The Communicator sampai kepada seluruh umat manusia. Karena yang dihadapi oleh para Nabi dan Rasul tersebut adalah penguasa maka komunikasi politik sebenarnya sudah terjadi pada saat itu. Seperti pada saat nabi Musa yang mempunyai masalah dalam hal berkomunikasi dan akhirnya memohon agar Harun mendampinginya untuk menghadap kepada Fira'aun. Ini menggambarkan bagaimana para Rasul harus menggunakan bahasa persuasif dan komunikatif

malaikat: "Bersujudlah kamu kepada Adam"; maka mereka pun bersujud kecuali iblis. Dia tidak termasuk mereka yang bersujud. 
kepada kaumnya agar dapat dipahami dan dipengaruhi kepada jalan yang benar ${ }^{2}$.

Manusia ditakdirkan sebagai Khalifah di muka bumi, khalifah adalah penguasa yang mempunyai tingkatan kesadaran tertinggi di antara makhluk lainnya di bumi yaitu berupa aqal pikiran. Manusia bisa melakukan inovasi dalam kehidupannya dan tidak menjalankan hidup sebatas menjalankan insting atau naluri yaitu bagaimana hanya bertahan hidup dan naluri berkembang biak. Maka kerusakan yang terjadi di bumi memang pelaku utamanya adalah manusia. Sejak adanya kehidupan di dunia suatu keniscayaan adanya pengelola atau pengendali yang mengatur dalam proses kehidupan. Sebagai makhluk sosial manusia akan selalu hidup dengan berkoloni atau bermasyarakat. Sehingga secara natural akan terseleksi adanya pengendali dan pengatur di antara mereka yang dinamakan seorang pemimpin.

Kalau kita melihat dari pesan yang ada di alam, kehidupan flora dan fauna ternyata semua saling terkait dalam suatu sistem mata rantai kehidupan. Mulai dari tumbuhan lalu adanya hewan herbivora yang memakan tumbuhan dan akhirnya ada hewan karnivora yang memakan hewan herbivora. Sehingga secara mata rantai karnivora memuncaki dari mata rantai kehidupan. Di alam hal itu adalah suatu yang wajar dan alami, sehingga konsekuensi mata rantai kehidupan agar terjadi suatu keseimbangan maka tumbuhan harus lebih banyak dari populasi hewan herbivora lalu populasi hewan herbivora harus lebih banyak dari populasi hewan karnivora.

Hal Ini dapat digambarkan dalam bentuk gambar segitiga seperti gambar dibawah ini:

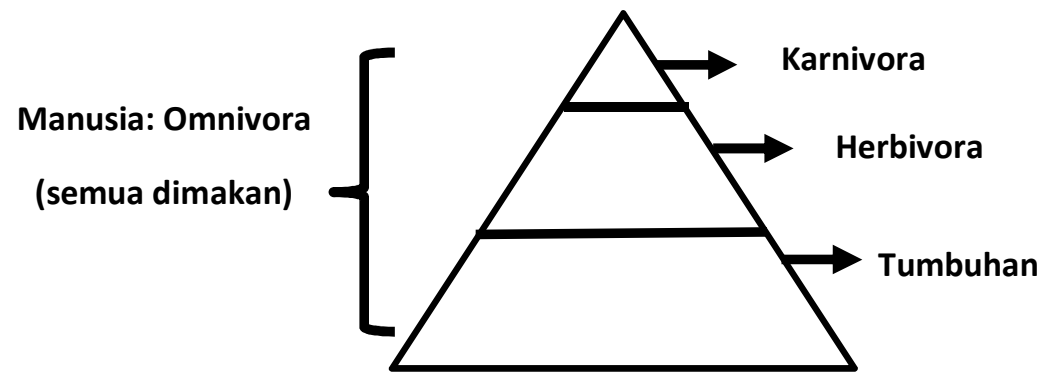

Gambar 1.1: Piramida Mata Rantai Kehidupan

Bagaimana posisi manusia pada mata rantai tersebut? Manusia bisa memakan semuanya. Walaupun ada suatu keyakinan atau ideologi

\footnotetext{
${ }^{2}$ Qs: Thaaha, 20/ 24 - 36 : "Pergilah kepada Firaun; sesungguhnya ia telah melampaui batas". Berkata Musa: "Ya Tuhanku, lapangkanlah untukku dadaku, dan mudahkanlah untukku urusanku, dan lepaskanlah kekakuan dari lidahku, supaya mereka mengerti perkataanku, dan jadikanlah untukku seorang pembantu dari keluargaku, (yaitu) Harun, saudaraku.
} 
menyangkut hal kuliner tersebut, ada yang memilih untuk vegetarian, ada yang berdasarkan keyakinan tidak boleh memakan hewan karnivora atau hewan tertentu. Apa yang dimakan oleh semua makhluk hidup ada yang memang mempunyai peran sebagai nutrisi, ada pula yang bersifat racun atau malah berakibat merusak. Apa yang dimakan akan mempunyai dampak atau konsekuensi menjadi sehat, tumbuh dan berkembang atau malah menjadi lemah dan sakit karena memakan yang bukan seharusnya atau karena terserang oleh bibit penyakit. Pada hakikatnya tidak ada yang salah terhadap apa saja yang ada di alam, tetapi karena manusia menggunakan atau memfungsikan sesuatu yang bukan ada tempatnya. Melihat gambar hierarki mata rantai tersebut di atas ternyata manusia adalah pemegang kuasa atau berkuasa dibanding makhluk lainnya di muka bumi ini. Maka manusia harus menggunakan kekuasaannya untuk menjaga keseimbangan alam. Namun, hal ini kembali lagi kepada manusia yang seperti apa yang akan dapat menjaga amanah ini. Alam akan rusak bila yang memegang amanah dan kekuasaan adalah orang yang berkhianat. Berkhianat akan dapat dijabarkan secara luas dengan berbagai bentuk perilaku yang menyimpang dari sistem keseimbangan alam itu sendiri.

Konflik yang terjadi di antara manusia menurut kitab suci adalah karena iri dengki berkaitan memperebutkan pasangan seperti pada kasus anak Adam yaitu Habil dan Qabil yang menyebabkan pembunuhan pertama di dunia. Melihat dari perspektif realita kehidupan, pasangan bisa juga diartikan partnership jadi bagaimana manusia akhirnya berbeda pendapat dan akhirnya membuat sebuah koalisi dan menjadi beberapa kubu (golongan) dalam menjalankan kehidupannya. Selanjutnya terkait dengan kebutuhan hidup yaitu urusan perut (makanan) termasuk yang menjadi awal mula manusia akhirnya berkonflik. Akhirnya untuk dapat menguasai sumber daya alam untuk manusia bertahan hidup yang mengembangkan kehidupannya, manusia akhirnya ingin menguasai wilayah atau tempat untuk dapat berkuasa penuh terhadap aset yang ingin dimilikinya. Maka konflikpun tak terhindarkan agar bisa memenuhi hasrat keinginannya. Maka wajarlah argumen Malaikat saat manusia ternyata dipilih untuk menjadi penguasa dengan karakter sebagai makhluk yang suka perang dan selalu menumpahkan darah $^{3}$.

Akhirnya, manusia yang secara naluri akan berusaha memperjuangkan hasrat keinginannya dalam rangka menguasai apa yang menjadi kebutuhannya, mulai dari kebutuhan primer, sekunder dan bahkan tersier (kemewahan). Manusia sebagai makhluk sosial tidak bisa melakukan segalanya seorang diri, maka manusia akan mencari dukungan yang akhirnya terciptalah golongan-golongan yang membentuk kelompok kekuatan. Maka

${ }^{3}$ QS: Al-Baqarah, 2/30 
terjadilah pertarungan untuk saling berkuasa dan mengalahkan lawannya. Siapa pun bisa terlibat dalam proses pertarungan tersebut, baik orang yang baik, orang jahat semua melebur dalam suatu proses yang terkait dengan kekuasaan. Seperti yang telah digambarkan sebelumnya berkaitan dengan hierarki mata rantai makanan, untuk terjadi keseimbangan di alam maka komposisi jumlah setiap makhluk digambarkan seperti segitiga. Dimana urutan dari yang paling sedikit jumlahnya sampai yang terbesar adalah: Karnivora - herbivora - tumbuhan. Karnivora harus agresif memburu hewan herbivora agar bisa bertahan hidup, dan herbivora juga harus terus mencari makanan yaitu tumbuhan yang tidak bergerak (pasif).

Aristoteles pernah menyimpulkan bahwa ' man is by nature a political animal 4 , yaitu manusia pada hakikatnya adalah hewan politik. Dengan demikian, manusia sejatinya tidak akan pernah bisa lepas dari aktivitas berpolitik. Kalau di analogikan maka dalam dunia politik yang berkaitan dengan khalayak yang ideal seperti digambarkan dalam hierarki segitiga di bawah ini berdasarkan pendapat Almond dan Verba: ${ }^{5}$

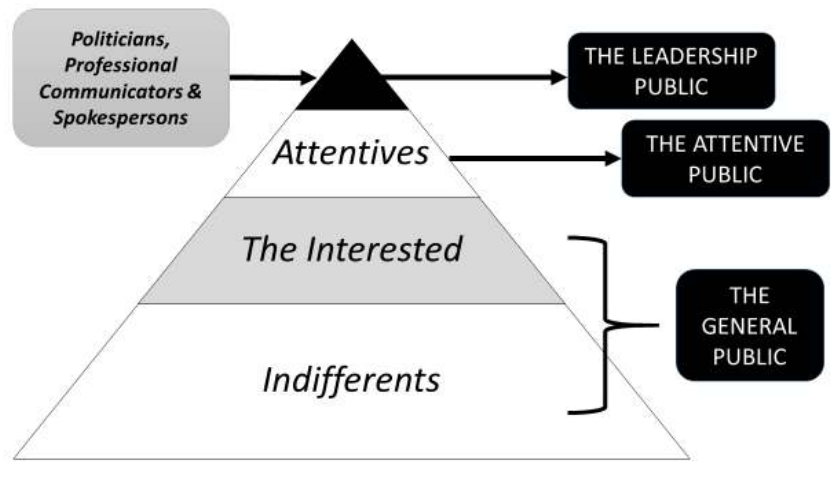

Gambar 1.2 Pelapisan Komunikasi Politik

Ada tiga lapis utama dalam masyarakat terkait perhatiannya terhadap politik, yaitu:

1. The leadership public atau disebut juga Elit opini yang terdiri dari para politisi ,para profesional dan juru bicara politik. Kelompok ini adalah kalangan yang paling berperan dan aktif minatnya terhadap masalah politik dan kepemerintahan, karena mereka terlibat langsung dalam proses dan peristiwa politik. Kelompok ini adalah penentu arah politik di suatu negara, bisa dikatakan jumlahnya sangat minoritas bisa jadi kurang dari 1\% dari populasi penduduk di suatu negara. Di negara demokrasi mereka adalah para pemenang pemilu baik pada pemilihan

4 R. G. Mulgan, Hermes; 102. Bd., H. 3 (1974), pp. 438-445;Published by: Franz Steiner Verlag;

Article Stable URL: http:/www.jstor.org/stable/4475868,

http://repository.up.ac.za/bitstream/handle/2263/14450/Papadis_Man_(2006).pdf?sequence=1

5 Zulkarimein Nasution: Komunikasi Politik Suatu Pengantar, (Jakarta: Ghalia Indonesia, 1990), hlm. 53 
legislatif maupun eksekutif dan orang-orang yang ditunjuk oleh para pemenang pesta demokrasi (legislatif, eksekutif dan yudikatif).

2. The Attentive public yaitu publik yang penuh perhatian, bisa dikatakan ini adalah lapisan masyarakat yang sudah sadar (aware), mau tahu dan menaruh minat kepada perkembangan dan dinamika politik. Menurut Almond (dalam Nasution, 1990: 48) disebut sebagai attentive stratum atau lapisan yang berperhatian, merupakan sub-kultur khusus, biasanya adalah kelompok-kelompok kepentingan berkembang, atau kelompok-kelompok yang merasa berkepentingan dengan masalahmasalah kebijakan umum ketimbang dengan kepentingan khusus. Jadi populasinya menurut perkiraan merupakan kelompok yang kurang dari setengah populasi orang dewasa atau kurang lebih 10 - 15\% dari populasi. ${ }^{6}$ Publik atentif adalah kelompok yang mudah dibedakan dengan kelompok lainnya7, karena mereka aktif melakukan kampanye untuk kandidat, aktif di partai atau sebagai aktifis dan relawan yang secara aktif berinteraksi dengan politikus, anggota parlemen atau pejabat yang terkait dengan tujuan yang sama dalam kegiatan politik.

3. General public, terdiri dari hampir separuh penduduk, dalam kenyataannya jarang berkomunikasi dengan para pembuat kebijakan. Bisa juga dikatakan sebagai komunitas masyarakat kebanyakan yang sering kali menerima informasi politik secara selintas. ${ }^{8}$ Mereka terdiri dari publik yang sekedar tertarik (interested) dan lebih banyak yang merupakan publik yang acuh tak acuh atau tidak peduli terhadap masalah politik (indifferent).

Fenomena yang terjadi di alam bisa jadi menjadi petunjuk dari segala proses yang terjadi dalam kehidupan manusia. Pada saat masa kuliah kita pernah mempelajari ilmu alamiah dasar dan ilmu budaya dasar. Dua disiplin ilmu yang berbeda dari sisi kajian dasarnya. Ilmu alamiah adalah bagaimana kita mempelajari apa yang terjadi secara natural di alam tanpa campur tangan manusia. Sehingga kita bisa menemukan pola atau cara bagaimana kehidupan itu bekerja. Semua yang ada di alam sangat terukur dan mempunyai takaran (standar) agar tercipta keseimbangannya. Bila ada yang kurang dalam takaran atau lebih dari takaran maka akan terjadi suatu kerusakan atau bencana, seperti tubuh kita contoh bila kurang vitamin akan lemah mudah terserang penyakit tapi bila kelebihan vitamin bisa membuat bahaya juga bagi tubuh manusia yaitu avitaminosis. Selanjutnya ilmu budaya dasar adalah ilmu yang mempelajari apa yang dikonstruksikan oleh akal dan pikiran manusia. Budaya muncul sebagai akibat dari bagaimana manusia yang selalu berusaha untuk

${ }^{6}$ Gun Gun Heryanto dan Irwa Zarkasy: Public Relations Politik, (Bogor: Galia Indonesia, 2012), hlm. 39

${ }^{7}$ Dan Nimmo, Komunikasi Politik: Khalayak dan Efek, Bandung: Remaja Rosdakarya, hlm. 49

8 Ibid. Hlm 39 
mempertahankan hidup dan melestarikan generasinya. Budaya bisa berbentuk fisik (artivek) atau nilai, adat istiadat, etika, bahasa dan juga bagaimana pola komunikasi antar sesamanya. Pada saat manusia berusaha melakukan sesuatu (trial and error) secara terus-menerus akhirnya mengukur segala bentuk tindakannya apakah benar-salah atau baik-buruk akan bercermin atau menjadikan rujukan dengan standar yang ada di alam atau bisa dikatakan adanya hukum alam. Walaupun terkadang ada jurang yang sangat lebar antara ilmu alam (eksakta) dan ilmu sosial (humaniora) dalam hal aplikasinya. Ilmu sosial menjadi sangat abstrak dan relatif.

Manusia akan selalu membaca petunjuk yang ada di alam dalam rangka memahami fungsi dan manfaat dari benda-benda, makhluk hidup lainnya seperti hewan dan tumbuhan. Sebagai contoh bagaimana manusia melihat bentuk anatomi kuda dengan pundaknya yang sangat pas diduduki oleh manusia dan kekuatan fisik kuda yang berbeda dengan hewan herbivora lainnya yang akhirnya disimpulkan kuda dijadikan alat transportasi pada zaman peradaban awal. Lalu manusia menciptakan alat-alat yang membantunya dalam melakukan kegiatannya, seperti ditemukannya roda yang akhirnya dikaitkan di kuda agar bisa membawa penumpang dan barang. Selanjutnya manusia menemukan bahan bakar di alam seperti batu bara dan minyak bumi, dan akhirnya diciptakanlah berbagai mesin dan juga pada saat ditemukan listrik muncullah lampu dan alat elektronik. Maka ada perubahan peradaban dari pola berburu, bertani dan akhirnya muncullah masyarakat industri.

Seperti halnya juga proses politik yang telah digambarkan ternyata tidak jauh berbeda bagaimana sistem kekuasaan di alam yang akhirnya membentuk segitiga seperti yang telah digambarkan diatas. Adanya The leadership public (elite opinion) adalah seperti populasi karnivora yang pasti paling sedikit dibanding jenis makhluk lainnya. Herbivora digambarkan sebagai publik atentif (publik yang punya perhatian) sehingga para elite opinion mempunyai ketergantungan dengannya, seperti bagaimana nasib hewan karnivora bila herbivoranya punah. Ini yang digambarkan oleh Nimmo ${ }^{9}$, publik atentif menempati suatu posisi penting dalam proses opini. Pentingnya posisi tersebut didasarkan pada kenyataan bahwa:

1. Lapisan publik inilah yang berperan sebagai saluran komunikasi antar pribadi dalam arus pesan yang timbal balik antara para pemimpin politik dengan publik umum. Publik berperhatian ini merupkan khalayak utama (key audience) baik bagi komunitor massa maupun komunikator organisasional.

2. Publik atentif menyertai para pemimpin politik sebagai pembawa (carrier) konsensus politik yakni orang-orang yang digambarkan dalam

\footnotetext{
${ }^{9}$ Nasution, op.cit. hlm 48
} 
bagian terakhir yang besar kemungkinannya daripada orang lain menunjang aplikasi spesifik aturan dan nilai-nilai umum demokrasi.

3. Publik atentif membentuk surruogate electorate atau pemilih bayangan dalam periode antara masa pemilihan. Para politisi biasanya mempersepsikan gelombang arus opini di kalangan publik atentif sebagai representasi dari apa yang diyakini, dinilai, dan diharapkan oleh publik umum (yang kurang berperhatian kepada politik semasa periode di antara dua pemilu). Dengan kata lain, khalayak yang mempunyai perhatian itu merupakan lapisan masyarakat yang berkemauan untuk mengikuti dalam perkembangan politik yang berlangsung.

Para teorisi demokrasi sejak Aristoteles hingga Bryce, menurut Almond dan Verb 10 telah menekankan bahwa demokrasi selama ini telah terpertahankan dan terpelihara berkat adanya partisipasi warga negaranya yang aktif dalam urusan kewargaan negara. Mereka itu dapat berpartisipasi dengan tersedianya informasi yang bertahap tinggi mengenai urusan-urusan masyarakat umum, dan oleh rasa tanggungjawab kewargaan negara yang tersebar luas. Doktrin-doktrin tersebut memberitahu kita, seperti apa seorang warga negara demokratis, jika dia berprilaku sesuai dengan tuntutan sistem. Jadi memang antara politisi, publik atentif dan publik umum saling terkait dalam sebuah sistem politik yang seperti digambarkan sistem mata rantai makanan di alam yang tak terpisahkan antara karnivora, herbivora dan tumbuh-tumbuhan. Apa yang akan terjadi bila alam ini hanya ada tumbuhan saja, atau bisakah karnivora tanpa adanya herbivora, bisa dikatakan akan terjadi ketidakseimbangan alam, yang ternyata antara hewan (karnivora dan herbivora) membutuhkan oksigen $\left(\mathrm{O}^{2}\right)$ yang dihasilkan tumbuhan, dan tumbuhan membutuhkah karbondiaoksida $\left(\mathrm{CO}^{2}\right)$ yang dihasilkan oleh hewan (karnivora, herbivora, dan omnivora).

Alat komunikasi politik dengan terminologi media komunikasi politik (political communication tools) dapat berupa media cetak, media elektronik dan cara-cara yang bersifat konvesional. Alat komunikasi politik, pada hakikatnya adalah untuk memperluas nuansa pandang dan berpikir yang tidak terbelenggu dengan kebekuan atau kekakuan egosentris yang dapat memperlebar jurang perbedaan. Fungsi yang paling dominan pada alat komunikasi politik adalah sebagai berikut: ${ }^{11}$

1. Alat untuk menyebarkan statement politik;

2. Alat informasi dan pendidikan politik;

3. Alat propaganda politik;

10 Ibid, hlm 49

11 Soemarno, AP, Materi Pokok Komunikasi Politik; 1-9; SKOM 4319 (Jakarta: Universitas

Terbuka, 2009), Hlm.1.9 
4. Alat konsolidasi dan konsensus nasional;

5. Alat sosialisasi politik.

Hakikat keberadaan media sangat memberi makna dominan bagi kehidupan manusia. Selain kehadirannya untuk memberikan rujukan kepada masyarakat tentang hal-hal yang belum diketahui atau tidak diketahui, media memberi manfaat pula untuk meminimalis pendapat yang berbeda dan untuk memberikan perbandingan tentang nilai yang sangat berguna bagi masyarakat. Media massa juga membuka cakrawala pandang peristiwaperistiwa yang berada di ruang waktu diberbagai belahan dunia. Media massa dapat menembus ruang dan waktu yang sulit ditembus secara personal. Faktor geografis tidak lagi menjadi hambatan utama yang selama ini menjadi masalah bagi Negara-negara yang tertinggal di bidang teknologi.

\section{B. Filsafat Komunikasi Politik}

Filsafat yang berkembang di Barat merupakan "master scientarium" atau induk dari segala ilmu, berbeda dengan pandangan ke-Ilahi-an bahwa sumber dari segala ilmu bersumber dari Sang Pencipta. Komunikasi politik bernaung pada dua diamentral filsafat, yaitu filsafat komunikasi dan filsafat politik. Hal ini mengandung makna bahwa kedua diamentral tersebut masing-masing bersifat spesies, sedangkan filsafat yang menaunginya bersifat genus. Spesies dalam artian khusus dan genus dalam artian umum. Filsafat komunikasi politik adalah renungan manusia tentang hakikat simbol-simbol kekuasaan dalam realitas keberadaannya di lingkup alam semesta. Dan pada hakikatnya, komunikasi politik adalah pengaktualisasian simbol-simbol komunikasi oleh manusia, baik sebagai penguasa maupun sebagai manusia biasa, dalam kehidupan sebagai masyarakat atau sekaligus dalam kehidupan bernegara.

Dalam teori relativitas, Einstein mengatakan bahwa kehidupan manusia pada dasarnya sebagai pengguna simbol. Hidup manusia dipengaruhi oleh simbol-simbol atau lambang-lambang. Alam yang telah diciptakan oleh Tuhan Yang Maha Esa berisikan pesan-pesan yang berupa simbol-simbol seperti yang difirmankan pada: Qs, Al-Imran, 3/190-191:

"Sesungguhnya dalam penciptaan langit dan bumi, dan silih bergantinya malam dan siang terdapat tanda-tanda bagi orang-orang yang berakal, (yaitu) orang-orang yang mengingat Allah sambil berdiri atau duduk atau dalam keadaan berbaring dan mereka memikirkan tentang penciptaan langit dan bumi (seraya berkata): "Ya Tuhan kami, tiadalah Engkau menciptakan ini dengan sia-sia. Maha Suci Engkau, maka peliharalah kami dari siksa neraka." 
Aayat dalam bahasa arab yang berarti tanda-tanda atau kode-kode dan simbolsimbol yang merupakan pesan tersirat kepada manusia agar manusia terus memikirkan segala penciptaan dan proses kehidupan, karena tidak ada yang sia-sia dalam segala penciptaan. Semua ada tujuan dan fungsi atau peran dalam segala penciptaan yang ada di alam semesta ini.

Simbol pada hakekatnya mewakili realita atau mewakili abstrak-abstrak yang tidak dapat dipersonifikasikan dalam alam pikiran dan perasaan. Simbol adalah mediator antara individu, kelompok, etnis kultur, bangsa dengan yang lainnya. Atau dapat pula dinyatakan bahwa simbol menghubungkan antara micro cosmos dengan macro cosmos. Dengan simbol tersebut, maka hambatanhambatan geo cosmos dapat diatasi, bahkan lebih daripada itu, peristiwa di berbagai belahan bumi dapat diketahui dan dapat dipantau. Lahirnya simbolsimbol tersebut pada hakekatnya sebagai produk kontrak simbol antar etnis budaya. ${ }^{12}$

Simbol-simbol itu lahir mengikuti kehadiran ummat manusia di dunia. Semakin manusia maju dan berkembang, semakin kompleks pula simbol yang digunakan. Manusia mulai menggunakan simbol-simbol komunikasi dalam pola-pola kehidupan bersama. Manusia yang tergabung dalam pola kehidupan, mempunyai simbol-simbol khusus atau tertentu, yang hanya dapat dipahami oleh kelompok bersangkutan. Simbol dapat dikategorikan ke dalam beberapa hal, yaitu: ${ }^{13}$

1. Bahasa, baik lisan dan tulisan;

2. Gambar-gambar;

3. Isyarat-isyarat;

4. Gerak-gerik dan raut muka.

Sedangkan, simbol dalam komunikasi politik adalah simbol-simbol kekuasaan dalam struktur kekuasaan dalam struktur dan dalam infrastruktur kekuasaan. Perbedaan simbol sebagai faktor penyebab berlangsungnya tukarmenukar simbol tidak lagi berlingkar pada skala kecil, namun telah melebar kepada skala yang lebih besar dan lebih luas. Secara krusial simbol-simbol tersebut, telah berkembang ke dalam norma-norma tertentu yang diwarnai oleh konsep-konsep pemikiran berbeda misalnya ideologi, yaitu pemikiran yang didasari pada nilai-nilai (value) tertentu. Simbol-simbol komunikasi yang berada dalam lingkup ideologi telah memiliki karakter pembeda, artinya telah memiliki kecenderungan atau apriori. Sebagai contoh, persepsi-persepsi yang disebut partai politik atau dalam terminologi komunikasi disebut monomorphic dan partai itu sendiri disebut homophily.

\footnotetext{
12 Soemarno, AP, Materi Pokok Komunikasi Politik; 1-9; SKOM 4319 (Jakarta: Universitas

Terbuka, 2009), Hlm.1.5

13 Soemarno AP, op.cit. hlm 1.6
} 
Pada tahap ini, individu yang mengikatkan dirinya pada partai dapat dikategorikan ke dalam empat tipe, yaitu:14

\section{Tabel 1.1: Tipologi Individu yang Mengikatkan Diri pada Partai}

\begin{tabular}{|c|c|}
\hline $\begin{array}{l}\text { Pertama } \\
\text { (Aktualisasi diri) }\end{array}$ & $\begin{array}{l}\text { - Individu yang mengikatkan diri pada partai adalah untuk } \\
\text { mengaktualisasikan dirinya dalam memenuhi kepentingan yang } \\
\text { hendak dicapai. } \\
\text { - Partai dijadikan alat atau mekanisme untuk mempercepat tercapainya } \\
\text { kepentingan tersebut. } \\
\text { - Simbol-simbol komunikasi diciptakan untuk mendapatkan dukungan } \\
\text { dan kepercayaan orang lain. }\end{array}$ \\
\hline $\begin{array}{l}\text { Kedua } \\
\text { (Merasa aman) }\end{array}$ & $\begin{array}{l}\text { - Dengan memasuki atau menjadi anggota partai akan merasa aman dari } \\
\text { tindakan dan sikap perilaku orang lain terhadap dirinya. } \\
\text { - } \quad \text { Partai sebagai instrumen untuk meningkatkan status sosial. }\end{array}$ \\
\hline $\begin{array}{l}\text { Ketiga } \\
\text { (Memperbaiki) }\end{array}$ & $\begin{array}{l}\text { - Individu yang betul-betul ingin memperbaiki situasi untuk kepentingan } \\
\text { bersama. } \\
\text { - Orientasi berpikirnya lebih pada kepentingan masyarakat, bahkan } \\
\text { untuk kepentingan nusa dan bangsa. }\end{array}$ \\
\hline $\begin{array}{l}\text { Keempat } \\
\text { (Terbawa arus) }\end{array}$ & $\begin{array}{l}\text { - Individu masuk dalam partai hanya terbawa arus dan tidak menghayati } \\
\text { maksud tujuan partai. } \\
\text { Komunikasi politik tidak diintrepretasikan ke dalam kepentingan } \\
\text { mereka. }\end{array}$ \\
\hline
\end{tabular}

Berbeda dengan tipe 1, 2, dan 4; tipe ke 3 untuk mencapai harapan individu, yaitu untuk melakukan perbaikan dan untuk kepentingan bersama, maka individu mulai mendekatkan diri pada sumber-sumber kekuasaan.

Hal ini mengandung makna setiap kepentingan tidak mungkin dapat terpenuhi apabila tidak ditransformasikan melalui lambang-lambang komunikasi. Karena secara filosofis, lambang-lambang komunikasi selalu menyertai kehidupan manusia baik secara individu, kelompok, masyarakat maupun secara organisasi atau partai politik. Keberagaman yang muncul pada simbol-simbol komunikasi politik bahkan terus berkembang mengikuti dinamika kehidupan masyarakat negara, seperti contoh istilah Orde Lama (ORLA), Orde Baru (ORBA), simbol yang melambangkan koalisi partai ada Koalisi Merah Putih (KMP) dan Koalisi Indonesia Hebat (KIH) pasca pilpres 2014, simbol garuda merah, kemeja kotak-kotak, istilah politisi kutu loncat, "papa minta saham", dan lain sebagainya. Hakekat simbol bagi suatu kelompok atau suatu organisasi merupakan personifikasi dari perilaku organisasi. Bahkan mewakili ungkapan pikiran, pendapat dan perasaan. Sebagaimana halnya manusia, organisasi pada hakikatnya adalah komunitas manusia, sehingga perilaku organisasi adalah cerminan perilaku manusia.

Kehadiran simbol komunikasi dalam kehidupan manusia, sesungguhnya untuk memelihara dan mempererat serta memperluas hubungan, baik dalam skala kecil maupun skala besar. Karena itu hakikat kehidupan manusia dalam mempertahankan kehidupannya adalah produk

14 Ibid, hlm 1.6 
pertukaran simbol. Tinjauan filosofis tentang simbol memberi makna sangat mendasar bagi kehidupan manusia. Bahkan seorang filsuf bernama Einstein berpedapat bahwa kehidupan empiris dan khayal yang sulit untuk diekspresikan. ${ }^{15}$ Simbol-simbol tersebut dalam proses komunikasi politik ataupun komunikasi pada umumnya adalah sangat penting, maka simbolsimbol yang digunakan harus merupakan produk "kesepakatan bersama" (symbol contract) yang akan memberi makna sebagai meaningful symbol atau simbol yang berarti. Makna simbol yang berarti adalah simbol yang dapat dipahami bersama, baik oleh komunikator maupun oleh komunikan. Demikian halnya dalam kehidupan kenegaraan, maka simbol-simbol yang digunakan harus dipahami oleh elit struktur kekuasaan, elit masyarakat dan warga negara pada umumnya, atau simbol-simbol yang digunakan dalam lingkup suatu sistem.

Simbol komunikasi politik yang digunakan dalam sub-sistem suprastruktur adalah simbol-simbol yang digunakan dalam struktur kekuasaan pada lembaga eksekutif, legislatif dan yudikatif. Sedangkan pada sub-sistem infrastruktur yaitu simbol-simbol yang tersebar secara bervariasi. Tinjauan filosofis terhadap simbol-simbol komunikasi politik lebih berorientasi pada partai politik, dengan tidak mengabaikan sub-unit sistem yang lainnya seperti: figur politik, kelompok penekan, kelompok kepentingan dan alat komunikasi politik. Simbol-simbol komunikasi yang berkembang dalam partai politik berdampak tajam terhadap simbol-simbol yang berkembang pada struktur kekuasaan bahkan antara keduanya bersifat berkaitan atau saling berpengaruh. Kondisi infrastruktur menunjukkan karakteristik suatu sistem politik. Pada negara penganut ajaran demokrasi, kehidupan infrastruktur sebagai faktor yang sangat menentukan kehidupan negara, karena struktur kekuasaan diisi oleh elemen infrastruktur melalui mekanisme pemilihan umum. Simbol-simbol politik pada partai politik merupakan produk kontrak simbol antar anggota partai untuk: 16

1. Menyamakan langkah partai dalam mencapai tujuan partai.

2. Menyamakan persepsi tentang kelangsungan hidup dan eksistensi partai.

3. Menentukan simbol-simbol yang efektif bagi perjuangan partai.

4. Komitmen moral terhadap sistem nilai yang berlaku dalam partai.

Oleh karena itu maka setiap partai memiliki unsur pembeda terhadap partai lain, karena perbedaan inilah maka perlu adanya konsensus yang memacu terwujudnya kolegialitas dan tingkat toleransi. Sedangkan simbolsimbol dalam kehidupan negara hakikatnya adalah untuk:

${ }^{15} \mathrm{Ibid}, \mathrm{hlm} 1.7$

${ }^{16}$ Ibid, hlm 1.8 
1. Mewujudkan karakteristik bangsa yang memiliki kepribadian (personality) sebagai suatu bangsa (nation).

2. Mewujudkan loyalitas warga negara terhadap negaranya.

3. Meningkatkan kualitas toleransi terhadap ego kelompok (partai).

4. Meminimalkan kondisi konflik yang merugikan negara.

Maka dari uraian di atas, dapat difahami bahwa kehadiran symbolsimbol komunikasi tidak sedekar pelengkap, namun sebagai suatu unsur yang sangat menentukan dalam kehidupan bernegara.

\section{Sejarah Komunikasi Politik}

Komunikasi politik seperti yang sudah diurai diawal, sudah ada sejak makhluk ada di alam semesta ini. Sejarah telah mencatat eksistensi bentukbentuk pemerintahan, mulai dari yang berbentuk kerajaan, pemerintahan otoriter, sampai dengan bentuk pemerintahan yang demokratis. Manusia yang hidup berkelompok akan memunculkan pemimpin diantara mereka, berkuasa adalah sebuah kepentingan untuk dapat menerapkan keinginan atau kehendak dari seseorang yang mempunyai gagasan atau bisa dikatakan sebuah ambisi. Sudah menjadi sesuatu yang natural bahwa manusia dengan latar belakang yang berbeda akan mempunyai pendapat yang berbeda terhadap suatu objek yang difahaminya (persepsi). Perbedaan pendapat dapat berujung dengan adanya konflik. Konflik inilah yang menjadikan manusia selalu berseteru dan bahkan akan memperjuangkan keinginannya. Maka dalam rangka mempengaruhi agar mendapatkan dukungan publik, munculkan teknik-teknik bagaimana memprovokasi atau lebih dikenal dengan propaganda. Fenomena inilah yang akhirnya memunculkan suatu kajian dibidang ilmu komunikasi politik.

Sejarah mencatat sejak penguasa-penguasa dahulu, dalam keperluan sistem politik suatu kerajaan atau negara dibangunlah struktur komunikasi khusus untuk menjaga kedaulatannya. Dalam rangka memelihara sumber (resources), bahkan biaya yang dikeluarkan juga cukup besar bagi lancarnya arus komunikasi dengan membangun infrastruktur di daerah kekuasaannya. Contoh di zaman Jengis Khan, kerajaannya mempunyai suatu sistem pengiriman surat (kurir) yang menghubungkan seluruh wilayah kerajaan dengan kecepatan yang mengagumkan. Kerajaan Mesopotamia (Mesir Kuno) mempertautkan arus komunikasi di wilayahnya melalui armada perahu yang melayari sepanjang sungai Nil. Dan di era sekarang, kita dapat melihat sendiri betapa setiap negara melengkapi diri dengan perangkat komunikasi satelit yang mampu memantau, mengirim informasi dengan cepat. Demikian pula perkembangan media massa dan media baru yang dapat dijadikan untuk kepentingan penyeberluasan informasi keseluruh wilayah atau teritorialnya. 
Studi mengenai komunikasi politik sudah ada sejak masa yunani kuno, menurut Pool (1965), studi-studi politik dapat dimasukkan ke dalam bibliografi mengenai komunikasi. ${ }^{17}$ Di antara studi tersebut dari yang klasik sampai yang modern dapat dilihat dalam bagan dibawah ini.

\section{Tabel 1.2: Pengelompokan berdasarkan Kajian Oral dan Tulisan}

\begin{tabular}{|l|l|l|}
\hline Tokoh & Buku (Karya) & Bahasan \\
\hline Plato & Gorgias (5 SM) & $\begin{array}{l}\text { Masalah moralitas dalam propaganda: seni } \\
\text { manipulatif atau teknik persuasi politik } \\
\text { yang bersifat transaksional dengan } \\
\text { menggunakan lambang untuk } \\
\text { mengidentifikasi pembicara dengan } \\
\text { pendengar melalui pidato, persuader dan } \\
\text { yang dipersuasi saling bekerja sama dalam } \\
\text { merumuskan nilai, kepercayaan dan } \\
\text { pengharapan mereka. }\end{array}$ \\
\hline Aristoteles & Rethoric (5 SM) & $\begin{array}{l}\text { Teknik persuasi melalui karakter (ethos) } \\
\text { etika pembicara, emosional (pathos) dan } \\
\text { argumen (logos) }\end{array}$ \\
\hline John Stuart Mill & $\begin{array}{l}\text { System of Logic } \\
\text { (1946) }\end{array}$ & \begin{tabular}{l} 
yang persuasif. \\
\hline
\end{tabular} \\
\hline
\end{tabular}

Hal ini seperti dikatakan oleh Deutsch dan Risselbach (1965) ${ }^{18}$ yang menekankan sumbangan sibernatika dan analisis isi. Mereka mengemukakan bahwa:

"persoalan penting yang dihadapi oleh para teoritis sejak Aristoteles hingga Montesquieu adalah sampai seberapa jauh keadaan manusia mempunyai kesamaan dalam politik dan sampai dimana keadaan tersebut dibentuk oleh semangat zaman dan negara, atau oleh orang?"

Selanjutnya Deutsch dan Risselbach mengajukan sebuah argument bahwa:

“....pendekatan utama untuk menjawab pertanyaan diatas adalah melalui studi komunikasi. Teori komunikasi dan pengendalian kadangkala disebut juga sibernatika, yaitu teori penyetiran atau memberi komando yang tumbuh pada akhir tahun 40-an dan dimasa tahun 50-an dalam sains dan teknologi. Beberapa implikasi intelektualnya disuarakan lewat karya-karya Shannon, Wiener, Von Neumann, Ashby, Miller, Cherry, Simon Newell dan lain-lain...."19

Menurut mereka berdua, beberapa pengertian dari tubuh ilmu komunikasi telah ditarik ke dalam teori pemerintahan dan politik. Konfigurasi teoritik yang umum dari saluran-saluran komunikasi dalam masyarakat, Bahasa dan kebudayaan sebagai kebiasaan komunikasi komplementer, tentang media massa, pengendalian dan isi pesannya. Daya ingat yang dimiliki

\footnotetext{
17 Nasution, op.cit. hlm 15

18 Ibid hlm16

19 Zulkarimen Nasution. Komunikasi Politik Suatu Pengantar.Jakarta: PT Ghalia Indonesia. 1990, hlm. 16
} 
seseorang dalam hal mekanisme penyaringan yang tidak terlihat yang mempengaruhi persepsi selektif, transmisi, dan daya simpan informasi pada populasi yang besar dan kecil kelompok kecil atau di dalam pikiran seseorang individu, semuanya telah diambil dan dipelajari. Lebih jauh dikatakan pula, bahwa teori komunikasi memungkinkan kita untuk melihat soal yang pelik seperti masalah kesadaran dan kemauan politik menjadi suatu proses yang dapat diamati. ${ }^{20}$

Tabel 1.3: Pengelompokan berdasarkan Media Massa dan Opini Publik

\begin{tabular}{|c|c|c|}
\hline Vladimir Lenin & $\begin{array}{l}\text { What is to be done } \\
\text { (1902) }\end{array}$ & $\begin{array}{l}\text { Membahas peranan surat kabar } \\
\text { Rusia dalam politik } \\
\text { revolusioner di masa Bolshevik. }\end{array}$ \\
\hline John milton & Areopagitica (1644) & $\begin{array}{l}\text { Membahas efek sistematis } \\
\text { dibolehkannya kebebasan } \\
\text { ekspresi dalam komunikasi. }\end{array}$ \\
\hline Walter Lippman & Public Opinion (1922) & Opini publik secara intensif. \\
\hline Arthur F. Bentley & $\begin{array}{l}\text { The process of } \\
\text { Gobernment: a Study } \\
\text { of Social Pressures } \\
\text { (1906) }\end{array}$ & $\begin{array}{l}\text { Studi mengenai cara-cara } \\
\text { kelompok-kelompok penekan } \\
\text { mempengaruhi politik dan } \\
\text { opini publik. }\end{array}$ \\
\hline David B. Truman & $\begin{array}{l}\text { The Governmental } \\
\text { Process: Political } \\
\text { Interests and Public } \\
\text { Opinion (1951) }\end{array}$ & $\begin{array}{l}\text { Mengenai proses pemerintahan } \\
\text { yang berkaitan dengan } \\
\text { ketertarikan politik dan opini } \\
\text { publik. }\end{array}$ \\
\hline
\end{tabular}

Komunikasi politik adalah perpaduan antara dua disiplin ilmu dalam satu rumpun ilmu sosial. Dalam domain politik, proses komunikasi mempunyai peranan yang sangat mendasar. Menurut Pye, "bagaimanapun, pendekatan komunikasi telah membantu memberikan pandangan yang mendalam dan lebih halus mengenai perilaku politik." 21 Menurut Nasution, hubungan antara komunikasi dan politik setidak-tidaknya dapat diulas dengan melihat: bagaimana interaksi kedua disiplin ini di bidang teori dan perkembangan konsep-konsep dan hubungan di antara kedua bidang itu dalam kehidupan nyata. ${ }^{22}$

Lahirnya ilmu komunikasi menurut Wilbur Schramm (1980) dibidani oleh empat orang yang sangat berpengaruh yang disebut sebagai the fouding fathers studi ilmu komunikasi, yaitu:

1. Paul Lazarsfeld (disiplin ilmu psikologi).

\footnotetext{
${ }^{20}$ Ibid. hlm 17

21ibid, hlm. 9

${ }_{22}^{2} \mathrm{Ibid}, \mathrm{hlm} 9$
} 
2. Kurt lewin (disiplin ilmu psikologi).

3. Harold D. Laswell (disiplin ilmu politik).

4. Carl Hovland (disiplin ilmu psikologi).

Lasewell (1902 -1980) menjadi satu-satunya yang berlatar belakang disiplin ilmu politik yang semasa hidupnya mengalami dua peperangan dunia pertama dan kedua, sehingga mempengarui berbagai tulisannya dalam bidang politik sampai pada tahap kajian khusus mengenai proses komunikasi dalam dunia politik.

Selanjutnya ada beberapa tokoh dalam ilmu politik yang memberikan sumbangan dalam mempertemukan ilmu komunikasi dan ilmu politik yang akhirnya melahirkan kajian disiplin ilmu komunikasi politik diantaranya adalah:

Tabel 1.4: Tokoh ilmuan politik dan komunikasi

\begin{tabular}{|c|c|c|c|}
\hline No & Nama & Karya (Tulisan) & Keterangan \\
\hline 1 & $\begin{array}{l}\text { Harold D. } \\
\text { Laswell } \\
\text { (1902-1980) }\end{array}$ & $\begin{array}{l}\text { - Propaganda Technique in the World } \\
\text { War (New York: Alfred A. Knopf). } \\
\text { (1927). } \\
\text { - Propaganda and Promotional } \\
\text { Activities: an Annotated } \\
\text { Bibliograpy (4.500 judul tulisan } \\
\text { propaganda dan kegiatan promosi), } \\
\text { bersama Ralph D. Casey dan Bruce } \\
\text { L. Smith (1935). } \\
\text { - Politic: Who Gets What, When, } \\
\text { How (New York: McGraw Hill, } \\
\text { 1936). } \\
\text { - World Revolutionary Propaganda: a } \\
\text { Chicago Study (bersama Dorothy } \\
\text { Blumensstock, New York Afred A. } \\
\text { Knopf, 1939). } \\
\text { The Language of Politic (bersama } \\
\text { Nathan Leites, Cambridge, Mass: } \\
\text { MIT Press, 1949). } \\
\text { - Propaganda, Communication, and } \\
\text { Public Opinion: a Comprehensive } \\
\text { Reference Guide (Princeton: } \\
\text { Princeton University Press, 1956). }\end{array}$ & $\begin{array}{l}\text { - Profesor di Yale } \\
\text { University, pionir dalam } \\
\text { studi analisis isi (Content } \\
\text { analysis). } \\
\text { - Bibliografinya diberi } \\
\text { judul One Hundred and } \\
\text { Fifty Outstanding Title } \\
\text { on Propaganda, } \\
\text { Communication, and } \\
\text { Public Opinion yang } \\
\text { merupakan pilihan dari } \\
\text { sekitar 3.000 judul karya } \\
\text { ilmiah mengenai } \\
\text { pembahasan bidang } \\
\text { komunikasi dan politik. }\end{array}$ \\
\hline 2 & $\begin{array}{l}\text { Itheil de } \\
\text { Sola Pool } \\
\text { (1917-1984) }\end{array}$ & $\begin{array}{l}\text { - The People Look at Educational } \\
\text { Television. } \\
\text { - Candidates, Issues and Strategies: a } \\
\text { Computer Simulation of The } 1960 \\
\text { Election Campaign. } \\
\text { - Trends in Content Analysis. }\end{array}$ & $\begin{array}{l}\text { Profesor dan pernah } \\
\text { mengetahui departemen } \\
\text { ilmu politik dan direktur } \\
\text { program riset mengenai } \\
\text { komunikasi internasional } \\
\text { di Massachussetts } \\
\text { Institute of Technology } \\
\text { (MIT) dan pernah } \\
\text { menjabat direktur proyek } \\
\text { penelitian komunikasi }\end{array}$ \\
\hline
\end{tabular}




\begin{tabular}{|c|c|c|c|}
\hline & & & $\begin{array}{l}\text { pada Hoover Institute, } \\
\text { Stanford University. }\end{array}$ \\
\hline 3 & $\begin{array}{l}\text { Valdi } \\
\text { mer } \\
\text { Orlando } \\
\text { Key, Jr. } \\
\text { (1908-1963) }\end{array}$ & $\begin{array}{l}\text { Public Opinion and American } \\
\text { Democracy (New York: Alfred A. } \\
\text { Knopf, 1961). } \\
\text { - The Responsible Electorate: } \\
\text { Rationality in Presidential Voting, } \\
\text { 1936-1960, (With Milton C. } \\
\text { Cummings) Belknap Press, } 1966 .\end{array}$ & $\begin{array}{l}\text { - Buku yang } \\
\text { menghubungkan prinsip- } \\
\text { prinsip komunikasi dan } \\
\text { sistem politik demokratis, } \\
\text { "menempatkan } \\
\text { pengetahuan yang lebih } \\
\text { baru tentang opini publik } \\
\text { dalam suatu konteks } \\
\text { politik". }\end{array}$ \\
\hline 4 & $\begin{array}{l}\text { Gabriel A. } \\
\text { Almond } \\
\text { (1911-2002) }\end{array}$ & $\begin{array}{l}\text { - Comparative Political Systems. } \\
\text { Gabriel A. Almond. The Journal of } \\
\text { Politics, Vol. 18, No. 3. (Aug, 1956), } \\
\text { pp. 391-409. } \\
\text { - "Aggressive Behavior by Clients } \\
\text { Toward Public Relief } \\
\text { Administrators: A Configurative } \\
\text { Analysis." 1934. American Political } \\
\text { Science Review 28(4): 643-655. (with } \\
\text { Harold D. Lasswell). } \\
\text { - Polling, Policy, and Public } \\
\text { Opinion: The Case Against Heeding } \\
\text { the "Voice of the People". 2002. } \\
\text { Weissberg, Robert. New York, } \\
\text { Palgrave Macmillan. }\end{array}$ & $\begin{array}{l}\text { Profesor ilmu politik di } \\
\text { Stanford University, yang } \\
\text { terkenal dengan } \\
\text { kajiannya mengenai } \\
\text { pemahaman komunikasi } \\
\text { politik dalam suatu } \\
\text { sistem politik. Bersama } \\
\text { Coleman (1960), Verba } \\
\text { (1966) dan Powell (1963 \& } \\
\text { 1978) }\end{array}$ \\
\hline 5 & $\begin{array}{l}\text { Lucian. W. } \\
\text { Pye } \\
(1921-2008)\end{array}$ & $\begin{array}{l}\text { - Communication and Political } \\
\text { Develompment (Princeton: Princeton } \\
\text { University Press, 1963) } \\
\text { - Power in Indonesia (sebagai editor } \\
\text { bersama Karl D. Jackson; } \\
\text { Berkeley.CA: University of } \\
\text { California Press, 1978) }\end{array}$ & $\begin{array}{l}\text { - Profesor yang pernah } \\
\text { menjabat ketua } \\
\text { departemen ilmu politik } \\
\text { MIT dan sebagai pelopor } \\
\text { dalam menjembatani } \\
\text { pemahaman komunikasi } \\
\text { dalam konteks } \\
\text { pembangunan politik. } \\
\end{array}$ \\
\hline 6 & $\begin{array}{l}\text { Frederick } \\
\text { W. Prey }\end{array}$ & $\begin{array}{l}\text { - Political Development, Power, } \\
\text { and Communications in Turkey," } \\
\text { Communications and Political } \\
\text { Development ed. }\end{array}$ & $\begin{array}{l}\text { - Profesor ilmu politik dari } \\
\text { MIT yang telah menulis } \\
\text { tentang konsep-konsep } \\
\text { mengenai komunikasi } \\
\text { dan pembangunan yang } \\
\text { merupakan suatu } \\
\text { pembahasan lintas } \\
\text { disiplin yang dapat } \\
\text { dikatakan paling } \\
\text { komprehensif (psikologi, } \\
\text { sosiologi, ekonomi dan } \\
\text { politik). }\end{array}$ \\
\hline 7 & $\begin{array}{l}\text { Karl W. } \\
\text { Deutsch } \\
(1912-1992)\end{array}$ & $\begin{array}{l}\text { - Nationalism and sosial } \\
\text { Communication (New York: Wiley } \\
\text { \& Sons, 1953). } \\
\text { - The Nerves of Government: Model of } \\
\text { Communication and Control (New } \\
\text { York: Free Press, 1963). }\end{array}$ & $\begin{array}{l}\text { - Ilmuan politik yang } \\
\text { memberikan kontribusi } \\
\text { penting dalam } \\
\text { pemahaman proses } \\
\text { komunikasi serta } \\
\text { hubungannnya dengan } \\
\text { proses politik. }\end{array}$ \\
\hline
\end{tabular}


Selain tokoh diatas ada pula Carter (1959) dengan analisisnya mengenai senator McCarthy yang dengan keahliannya menjalin hubungan baik dengan pers. Lalu Gostnell (1936) yang membahas kaitan antara analisis khalayak (audience analysis) dengan medium, dan dengan analisis peristiwa-peristiwa politik. Selanjutnya Zulkarimein Nasution ${ }^{23}$ juga memaparkan sejumlah karya utama penelitian komunikasi yang langsung menghampiri bidang politik adala penelitian mengenai perilaku pemberian suara (voting study) dan pengaruh komunikasi massa bagi respon khalayak terhadap kampanye dan keputusan pemberian suara yang mereka lakukan dalam pemilihan umum. Studi-studi tersebut antra lain:

- The People's Choice oleh Paul L. Lazarsfeld, Bernard Berelson, dan Hazel Gaudet (New York: Colombia University Press, 1944).

- Voting, a Study of Opinion Formation in a Presidential Campaign oleh Belerson, Lazarfeld dan McPhee (Chicago: University of Chicago Press, 1954).

- Personal Influence: the Part Played by People in the Flow of Mass Communications oleh Elihu' Katz dan Lazarsfeld (Glencoe, Illinois: The Free Press, 1955).

- The Voter Decides oleh Cambell, Converse, Miller, dan Stokes (New York: Wiley, 1960)

Karya-karya diatas dipandang sebagai karya pelopor mengenai survey pemilu. Studi mengenai voting tersebut telah meluas ruang lingkupnya, karena telah mencoba untuk menjelaskan lebih sekedar prilaku pemberi suara. Studi-studi tadi telah menyentuh juga masalah-masalah partisipasi politik dalm arti luas, informasi politik, kepuasan yang diperoleh individu dari politik, motif mereka dalam berpartisipasi dan sebagainya. Semua karya-karya dan kajian serta penelitian seperti puzzle yang membangun keilmuan bidang komunikasi politik.

Kaitan dengan media massa karya Joseph T. Klapper, The Effects of Mass Media (New York: Colombia University, Bureau of Applied Social Research, 1949) dan The Effects of Mass Communication (Glencoe, Illinois: The Free Press, 1960) yang merupakan review terpadu tentang efek komunikasi massa di berbagai bidang termasuk politik. Kata kunci (key word) dalam kajian komunikasi dan politik seperti: efek politik media massa, sosialisasi, propaganda, kampanye, peranan politik pers, pembentukan dan perubahan sikap (attitude), opini public, kepemimpinan opini, perilaku media, dan yang berkembang di tahun 2000 an adalah berkembangnya Public Relation politik,

${ }^{23} \mathrm{Ibid}, \mathrm{hlm} 14$ 
marketing politik, studi di sosial media dan sebagainya. Sebagai contoh bila kita mengkaji masalah pemilu adalah bidang atau ranahnya hanya kajian politik.

Tapi saat kita mengkaji proses yang terjadi pada saat pemilu sebelum, sedang dan akan seperti kampanye, sosialisasi politik, dan lainnya adalah masuk ke bidang kajian komunikasi politik, ini yang harus bisa dibedakan dari kontennya. Kajian yang menyangkut bidang politik dalam kaitannya dengan proses komunikasi dapat disimpulkan bahwa hubungan antar disiplin komunikasi dan politik baik pada tingkat teori, konsep-konsep, maupun penelitian telah terjalin sejak awal perkembangan dua disiplin tersebut sampai dengan hari ini dengan perkembangan adanya media baru atau komunikasi politik melalui media sosial dan era digital.

Ilmuan politik memberikan perhatian yang lebih terhadap efek nonpersuasif komunikasi. Hal ini dikarenakan ilmuan politik tertarik akan masalah-masalah ideologi-ideologi yang dikomunikasikan dan penggunaannya dalam kegiatan politik walaupun aspek pesuasinya hanya sedikit. Laswell yang sejak lama telah mengemukakan pentingnya menghimpun data kuantitas yang pasti (exact) mengenai distribusi simbolsimbol ideologis di dunia. ${ }^{24}$ Pada tahun 1930 menjadi pelopor penggunaan analisis isi atau content analysis sebagai suatu alat untuk memperbandingkan propaganda politik pada masa dan tempat yang berbeda. Penelitian itu diteruskan di Library of Conggress di masa perang Dunai II dan Hoover Institute setelah perang usai. ${ }^{25}$

Selanjutnya secara garis besar sejarah komunikasi politik digagas oleh beberapa tokoh yang sangat menonjol dalam proses terbentuknya, yaitu menjadi beberapa era:26

\footnotetext{
${ }^{24}$ Karin Dovring, "Harold Dwight Lasswell His Communication with a Future", 1988: http://web.asc.upenn.edu/gerbner/Asset.aspx?assetID=867, hlm 11; The analysis of undercurrents has been at the heart of much of Lasswell's analysis of controversial issues. Lasswell exposed this propaganda technique by developing attention surveys of the word' press.

25 Nasution, op.cit. hlm 15

26 Rogers, E. M. (2004). Theoretical diversity in political communication. dalam Kaid, L. L. (Ed.). (2004) Handbook of political communication research, hlm. 3-16.
} 

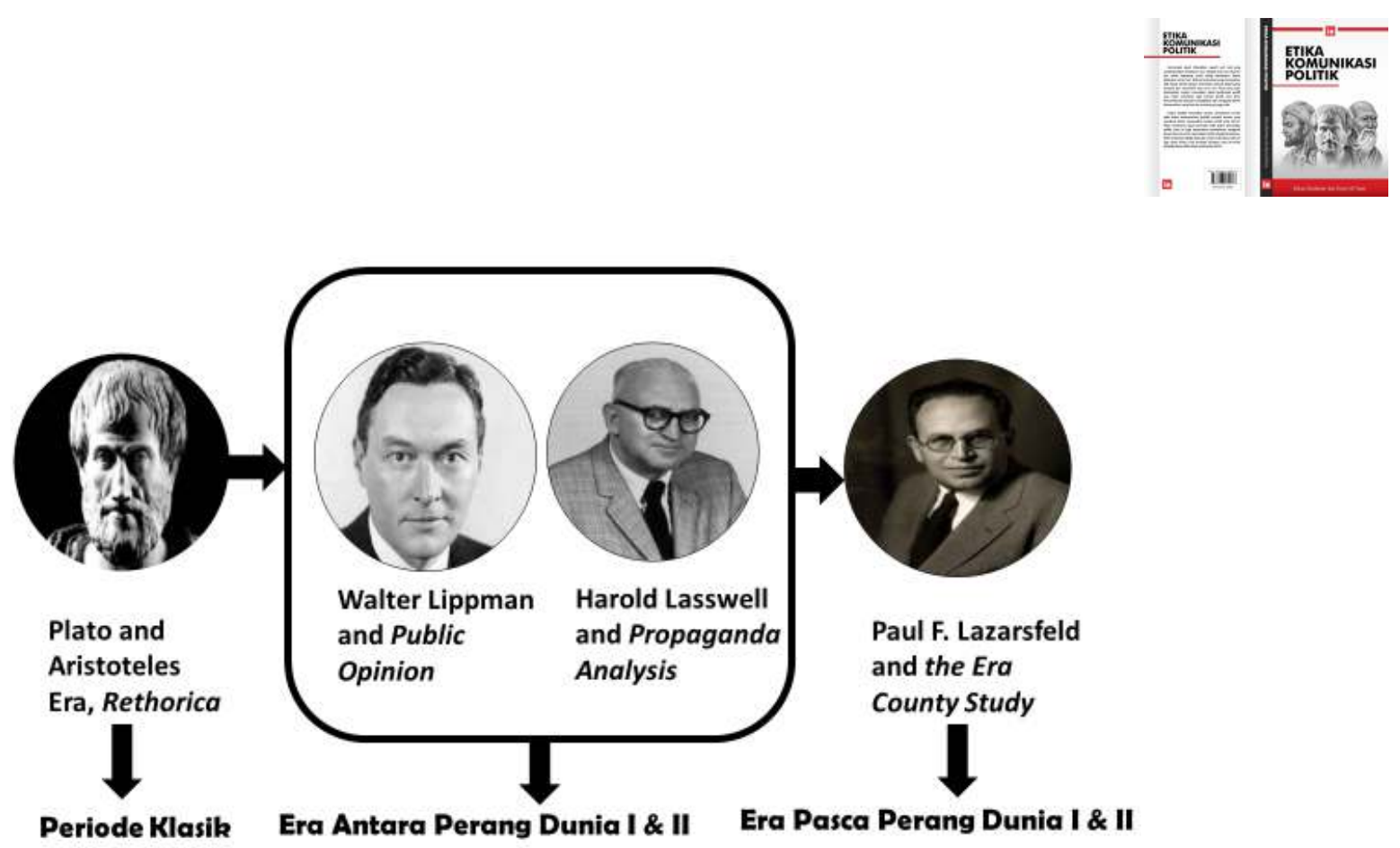

Gambar 1.3 Tokoh-Tokoh Pelopor Komunikasi Politik

\section{Era Plato and Aristoteles (Periode Klasik)}

Pada periode ini kajian mengenai komunikasi politik belumlah mendalam dan secara detail membahas mengenai komunikasi politik, melainkan lebih kepada kajian retorika yang dinilai sebagai kajian paling spektakuler pada zaman itu. Karena pada zaman itu pembuatan kebijakan publik berdasarkan pada pendapat umum dan disini retorika digunakan untuk mempengaruhi pendapat umum yang dapat menentukan kebijakan publik khususnya bangsa Yunani dan Romawi. Sehingga, bangsa Yunani dan Romawi memanfaatkan studi komunikasi untuk mempengaruhi pendapat umum tersebut agar berimbas pada kebijakan publik yang biasa disebut dengan retorika. Karena penggunaan komunikasi mereka berimbas pada sistem politik pada saat itu maka ini dapat disebut sebagai komunikasi politik. Sejak saat itulah studi komunikasi politik mulai berkembang, walaupun kajian khusus mengenai gejala komunikasi juga belum ditemukan pada zaman itu. Periode ini berlangsung sejak masa sebelum masehi dan berakhir sekitar tahun 1940an.

\section{Era Antara Perang Dunia I dan II}

Periode ini berlangsung pada kurun waktu sesudah seperempat abad pertama abad 20 hingga dekade 1950-an. Dalam periode ini terjadi perang dunia pertama dan kedua, di dalam perang dunia tersebut pihak-pihak yang bermusuhan saling melontarkan propaganda. Sehingga, dalam periode ini lebih banyak membahas mengenai propaganda dikarenakan hal tersebut sangat memberikan dampak besar terhadap jalannya perang dunia. Karena dalam periode ini propaganda dianggap penting, munculah beberapa karya 
penting yang membahas propaganda seperti karya Harold D Laswell pada tahun 1927 yang berjudul "Propaganda Technique in The World War", karya Alfred McClung dan Elisabeth B Lee yang berjudul "The Fine Art of Propaganda" pada tahun 1939.

Studi mengenai efek media adalah bagian dari program penelitian yang sedang berlangsung yang dimulai dari karya ilmiah Harold Laswell, seorang ilmuwan politik di Universitas Chicago yang mengkhususkan diri pada penelitian mengenai propaganda. Disertasi doktor Harold D. Laswell di Universitas Chicago, yang kemudian diterbitkan menjadi sebuah buku, ${ }^{27}$ berisikan analisis isi terhadap efek pesan propaganda oleh pemerintah Jerman melawan Perancis, Inggris dan Amerika selama Perang Dunia I. Laswell menyusun sebuah metode untuk melakukan analisis isi pesan media massa. Dia terkenal dengan model lima pertanyaan komunikasi (five-question model of communication): who says what to whom via which channel with what effects?

Pada waktu itu, konsep Laswell itu sangat berpengaruh dalam penelitian mengenai efek media, dan tanpa disadari, dalam batas-batas tertentu pengaruhnya masih bisa dirasakan hingga saat ini. Meskipun Laswell memeroleh gelar doktornya di bidang ilmu politik, namun minat keilmuwannya membentang demikian luas, dan di masa akhir karirnya, setalah dia meninggalkan Universitas Chicago, ia pun menspesialisasikan diri pada pengembangan riset komunikasi. Selama berlangsung Perang Dunia II, Laswell dengan didanai oleh Yayasan Rockefeller, memimpin sebuah tim penelitian di Perpustakaan Konggres Amerika Serikat, dengan tugas melakukan analisis isi terhadap pesan propaganda Allied and Axis di media massa.

Pada tahun 1944, pemilik koorperasi Time-Life, Henry Luce, menyediakan dana untuk jangka waktu 3 tahun guna melakukan kajian terhadap media massa di Amerika Serikat oleh Komisi Kebebasan Pers. Ke-13 anggota komisi, dipimpin oleh Robert Hutchins, Presiden Universitas Chicago, memasukkan Laswell sebagai anggota yang sangat berpengaruh. Komisi ini menaruh perhatian besar pada makin bertambahnya pemusatan kepemilikan media di AS dan makin berkurangnya persaingan di antara surat kabar yang ada. Komisi membuat laporan dengan penekanan pada diupayakannya masyarakat yang sadar informasi sebagai tujuan dari demokrasi.

Para pengamat menilai karya Walter Lippmann sebuah buku yang berjudul Public Opinion (1922) merupakan dokumen yang menandai lahirnya studi komunikasi. Lippmann bersama dengan Harold D. Laswell adalah ilmuwan kontemporer yang menekuni kajian mengenai propaganda dan opini publik. Selama berlangsungnya perang dunia I, Lippmann bekerja melayani

27 Everett M. Rogers, dalam Handbook of political communication research / edited by Lynda Lee Kaid, hlm 5 
sebagai penulis leaflet propaganda untuk Alled Army di Perancis. Selama era di mana studi komunikasi dikembangkan sekitar tahun 1920-an, 1930-an hingga menjelang tahun 50-an dan 60-an, propaganda menjadi subjek yang utama bagi para ahli komunikasi. PD I merepresentasikan sebuah peperangan di mana para pelakunya menggunakan propaganda sebagai senjata andalan, dan masyarakat mempersepsi teknik propaganda sebagai senjata yang ampuh yang membahayakan. Persepsi semacam ini sebetulnya hanya didasarkan pada bukti-bukti anekdot yang didengar dan klaim berlebihan yang dilakukan oleh pemerintah dan tidak didasarkan atas analisis ilmiah. Ketakutan publik akan kekuatan propaganda akhirnya membuat mereka tertarik pada studi awal yang dilakukan oleh Lippmann dan Laswell. Pada kenyataanya, bidang studi yang kemudian kita kenal sebagai "komunikasi massa" dulunya disebut sebagai "public opininon and propaganda", tahun 1930-an. Laswell mengajarkan materi kuliah dengan nama itu di Universitas Chicago. ${ }^{28}$

Pemikiran awal Lippmann (1922) dan tulisan-tulisannya kemudian kita kenal sebagai proses agenda-setting; salah satunya tertuang dalam chapter berjudul "The World Outside and the Picture in Our Heads". Lippmann membandingkan antara "the real-world indicators" dengan persepsi masyarakat terhadap suatu persoalan (kemudian kita kenal sebagai agenda publik), ini menjadi ukuran penting tidaknya beberapa problem sosial yang terjadi dalam realita di masyarakat. Walter Lippmann menjadi pioner di dalam studi analisis isi, berupa analisis liputan The New York Times dalam peristiwa Revolusi Rusia tahun 1917. Lippmann dan Merz (1920) menemukan bias antiBolshevik dalam liputan berita tersebut, yang akhirnya menuntun Lippmann kepada rasa tidak percayanya pada kemampuan rata-rata anggota masyarakat Amerika untuk bisa berpendapat secara intelektual tentang persoalan penting yang sedang terjadi. Walter Lippmann disebut sebagai jurnalis yang paling berbakat dan berpengaruh di abad ke-20 ini. Dan diapun dinobatkan sebagai analis kunci dalam kajian propaganda dan opini publik termasuk terhadap kajian agenda-setting.

Nama Lippmann menjadi tokoh penting dalam identifikasi peranan media massa terhadap terbentuknya opini publik dalam negara demokrasi. Ia berpendapat bahwa media, yang kebebasannya dijamin oleh Amandemen Pertama, posisinya menjadi sangat krusial di dalam penciptaan "pasar bebas gagasan".

"The value of participatory democracy, active and widespread popular participation informed by a free and responsible press, serves as an important impetus to political communication research" ${ }^{29}$

\footnotetext{
${ }^{28}$ Ibid, hlm 5

${ }^{29}$ Ibid, hlm 4
} 
Studi komunikasi politik pun mendapat angin segar sejak awal oleh adanya perhatian normatif terhadap kebutuhan akan adanya press yang bebas dan masyarakat dapat memperoleh informasi dengan semestinya.

\section{Era Pasca Perang Dunia I dan II}

Periode ini terjadi pada sekitar pertengahan dekade 1950-an hingga awal tahun 1970-an. Pada periode ini awalnya ditandai dengan temuan riset mengenai pengaruh media terhadap sikap, keputusan, dan perilaku. Pada masa itu para peneliti seperti Paul Lazarfeld, Robert K Merlon, dan Joseph Keppler mengidentifikasi adanya pengaruh komunikasi antarpribadi dalam pembuatan opini. Sehingga pada periode ini lebih menekankan pada efek media yang umumnya dalam jangka pendek terhadap variable politik seperti identifikasi individu terhadap partai politik, penilaian terhadap kandidat, preferensi politik dan perilaku pemilih. Dalam periode ini juga berkembang pendekatan sistem yaitu dipertimbangkannya variable komunkasi dalam proses atau sistem politik serta juga berkembang konsep feedback dan analisis input serta output. Selain itu, dalam periode ini juga mengkaji mengenai peran apa yang dapat dimainkan dengan komunikasi serta studi komunikasi pembangunan hingga akhir 1980-an.

Paul F. Lazarsfeld, ilmuwan imigran dari Austria, yang menghabiskan hampir sebagian besar waktu karirnya di Columbia University. Memelajari matematika, Lazarsfeld menjadi pemain kunci yang teramat penting di dalam riset ilmiah dalam penelitian efek komunikasi massa. Ia memimpin Proyek Penelitian Radio, yang didanai oleh Yayasan Rockefeller di tahun 1937, yang melakukan eksplorasi efek-efek yang ditimbulkan radio terhadap khalayak Amerika. Lazarsfeld memindahkan proyek penelitian radio ke biro riset sosial terapan di Universitas Columbia, yang tidak diragukan dikenal sebagai lembaga pendidikan berbasis riset pada masa itu dan salah satu spesialisasinya adalah pada riset komunikasi.

Bersama dengan kolega ilmuwan sosiologinya, Robert K. Merton, Lazarsfeld mengembangkan metode penelitian wawancara kelompok terfokus (FGD) ${ }^{30}$, sebuah teknik pemerolehan data yang digunakan dalam kajian mengenai iklan radio mengenai pentingnya masayarakat Amerika menanam Victory Gardens, mengumpulkan besi bekas dan karet-karet bekas dan membeli surat obligasi perang. Kampanye pemerintah federal ini, pada dasarnya merupakan propaganda domestik, yang dirancang dan dievaluasi oleh sejumlah ilmuwan komunikasi yang berasal dari berbagai latar belakang

${ }^{30}$ Everett M. Rogers, dalam Handbook of political communication research / edited by Lynda Lee Kaid, hlm 6 
ilmuwan sosial, termasuk Laswell, Lazarsfeld, Wilbur Schramm dan yang lainnya.

Lazarsfeld dipercaya memimpin riset kuantitatif yang pertama tentang perilaku politik, dengan sebuah penelitian yang kemudian menjadi sangat terkenal dengan nama the Erie County Study tahun 1940, dan merupakan bentuk penghargaan terhadapnya selaku pioner penelitian komunikasi politik yang paling penting. Lazarsfeld dan rekan-rekannaya mengadakan 600 wawancara personal selama enam bulan hingga berlangsungnya pemilihan presiden November 1940. Studi ini dilakukan di Erie County, Ohio, ditentukan oleh para peneliti Universitas Columbia sebagai wilayah yang mewakili Amerika Serikat.

Tujuan yang ingin dicapai Lazarsfeld dalam the Erie County Study ini adalah melakukan penelitian tentang pentingnya efek langsung media di dalam menentukan pilihan masyarakat dalam pemilihan presiden. Variabel terpengaruh yang utama dalam penelitian ini adalah perilaku memilih, mencerminkan latar belakang Lazarsfeld yang pernah melakukan riset pemasaran (Lasarsfeld termasuk salah satu pendiri riset pemasaran di Amerika Serikat). Sebagaimana dinyatakan oleh Chaffee dan Hockheimer: ${ }^{31}$

"Pilihan terhadap kandidat menjadi ukuran utama sebuah variabel, seakanakan itu menjadi tindakan politik yang paling penting yang bisa dilakukan oleh seseorang. Fokus dari pemilihan ini diikuti oleh banyak peneliti sejak tahun 1940-an. ..."

Tidak ada yang mengingkari bahwa pilihan (voting) adalah aspek yang penting dalam perilaku politik, namun kontribusai waktu dan uang dalam kampanye pemilihan, pernyataan seseorang kepada yang lain yang mendukung suatu kandidat, ajang pameran poster dan pin kampanye, dan tindakan politik lainnya juga merupakan hal yang penting (Chafffe\&Hockheimer,1985). ${ }^{32}$ Variabel utama dalam the Erie County Study, disamping terpaan surat kabar dan majalah berita serta radio (media utama pada masa 1940-an) adalah status sosio-ekonomi individu dan identifikasi terhadap partai politik.

Yang mengejutkan Lazarsfled adalah, hanya 54 dari 600 responden dalam the Erie County Study yang mengalami pergeseran (pilihan) dari satu kandidat presiden ke kandidat presiden yang lain, dan hanya sedikit dari mereka ini yang perubahannya secara langsung dipengaruhi oleh apa yang disajikan media (Converse, 1987). ${ }^{33}$ Banyak di antara pemilih yang telah membuat keputusan tentang siapa pilihannya sebelum kampanye pemilihan berlangsung. Lazarsfeld, Berelson dan Gaudet (1944) menyimpulkan bahwa

${ }^{31}$ Ibid, hlm 6

$32 \mathrm{Ibid}, \mathrm{hlm} 6$

$33 \mathrm{Ibid}, \mathrm{hlm} 5$ 
media hanya memiliki efek minimal dalam kampanye pemilihan presiden 1944. Meski demikian, ahli-ahli lainnya Chaffee \& Hockheimer, 1985) ${ }^{34}$ mempertanyakan simpulan tersebut, mereka berpendapat, bisa jadi persoalannya terletak pada interpretasi data dan jenis data yang menjadi pertimbangan penelitian (Everett M. Rogers,1994). ${ }^{35}$

Dalam peristiwa yang lain, Lazarsfeld dan rekan lainnya mengeluarkan sebuah postulat tentang two step flow of communication di mana pemimpin opini dengan tingkat terpaan media yang relatif tinggi kemudian menjadi perantara informasi politik terhadap para pengikutnya melalui saluran komunikasi interpersonal. Model komunikasi dua tahap menunjukkan adanya saling melengkapi antara peran media massa dengan komunikasi interpersonal dan inilah yang seringkali terjadi dalam pengambilan keputusanpolitik individu. Ini yang kemudian diikuti dalam penelitian berikutnya hingga saat ini (Everett M. Rogers,2002a). ${ }^{36}$

Dalam beberapa tahun setelah penelitian the Erie County Study, para ahli komunikasi terkesan terlampau menekankan pada efek minimal dari media massa. Rekan paling yunior Lazarsfeld di Biro Riset Terapan di Universitas Columbia, seorang sosiolog Joseph Klapper (1960), menyimpulkan dalam bukunya berjudul The Effect of Mass Communication bahwa media jarang memiliki efek langsung. Pada saat itu, seperti sudah menjadi asumsi dalam riset komunikasi massa yang dilakukan, simpulan semacam itu tampaknya terlalu berlebihan. Dalam perkembangan berikutnya, meski demikian, simpulan tentang efek minimal ini kembali dipertanyakan.

Bersamaan dengan pemilihan presiden tahun 1948, maka dilanjutkanlah penelitian semacam di the Erie County Study tersebut, kali ini mengambil lokasi masyarakat di wilayah New York. 37 Ini merupakan penelitian Lazarsfeld pertama yang berskala besar dalam riset pemilihan presiden yang memberi perhatian utama pada peran media massa dan agaknya belum pernah ada lagi penelitian semacam ini di tahun-tahun berikutnya. ${ }^{38}$ Lembaga Riset Sosial Universitas Michigan memulai studi secara berkelanjutan tentang pemilihan presiden, melanjutkan tradisi riset survai dari Lazarsfeld tentang perilaku memilih.

Survei nasional ini, meski demikian, hanya sedikit menaruh perhatian terhadap peran media massa dalam keputusan memilih, dan sebaliknya memusatkan pada variabel identifikasi partai politik dan variabel sosio-

\footnotetext{
$34 \mathrm{Ibid}, \mathrm{hlm} 5$

${ }^{35}$ Ibid, hlm 5

${ }^{36} \mathrm{Ibid}, \mathrm{hlm} 5$

37 Berelson, Lazarsfeld, and McPhee. 1954. Voting. Chicago: University of Chicago Press, http://wikisum.com/w/Berelson,_Lazarsfeld,_and_McPhee:_Voting

38 Chaffee\& Hockheimer, 1985 dalam Handbook of political communication research / edited by Lynda Lee Kaid, hlm 5
} 
ekonomi sebagai variabel yang berpengaruh dalam sebuah pengambilan keputusan memilih seseorang (pentingnya partai politik dalam menentukan perilaku memilih warga telah memudar dalam tahun-tahun terakhir ini, digantikan oleh media, khususnya televisi). Karena penelitian Michigan ini merupakan sampel survei berskala nasional, peran jaringan komunikasi personal dalam keputusan memilih menjadi sulit atau tidak memungkinkan untuk dikaji. ${ }^{39}$ Posisi utama individu sebagai unit of respons dan menjadi unit analisis menjadikan tidak ditekankannya jaringan dan pengaruh sosial lainnya terhadap keputusan memilih dan makin berkurangnya perhatian pada sistem yang lebih besar seperti institusi media di dalam penelitian komunikasi politik.

\section{Era sesudah kuartil ketiga abad ke 20}

Dalam periode ini yang berlangsung sesudah kuarti ketiga abad ke 20 hingga akhir abad 20, komunikasi politik yelah berkembang sebagai sub disiplin ilmu. Sebagai disiplin ilmu, munculah ragam pendekatan teoritik seperti agenda setting, framing, feminism, ekonomi, politik, dan postmodernism. Selain itu, dalam periode ini komunikasi politik juga merambah pada persoalan peran media massa saat terjadi konflik.

\section{Era Terkini}

Pada masa sekarang ini studi komunikasi politik berkembang dikarenakan cara atau metoda komunikasipun mengalami perubahan yang lebih maju. Terutama setelah ditemukannya teknologi komunikasi mulai dari adanya telegraf, telepon kabel laku diluncurkannya satelit dengan penggunaan pengiriman sinyal gelombang eletromagnetik dan akhirnya muncullah telepon seluler, sampai dengan penggunaan internet sebagai saluran atau kanal telekomunikasi. Maka inilah yang disebut "Era Digital". Dengan realitas yang demikian maka semakin berkembanglah penelitan dan kajian mengenai komunikasi politik, tidak hanya soal demokrasi, pemilu, pendapat umum, konflik, budaya gap, gender, etnisitas, multikultural, dan modernisasi, dan juga penggunaan media baru (media sosial) dalam penyampaian pesan-pesan politik. Inilah era atau zaman dimana studi komunikasi politik telah merambah dan diaplikasikan ke dalam berbagai bidang dan juga karena masalah politik sudah cukup kompleks karena berkembang dalam berbagai bidang, sehingga studi komunikasi politik digunakan sebagai salah satu sub disiplin ilmu.

Dapat dilihat bahwa perkembangan komunikasi politik dipengaruhi oleh peristiwa atau suatu hal yang berpengaruh terhadap politik pada zaman tertentu. Sebagai contoh, ketika pada zaman Yunani masih menggunakan pendapat umum sebagai penentu kebijakan, mereka menerapkan sistem retorika sebagai alat politik, selain itu pada masa perang dunia studi komunikasi politik juga dipengaruhi oleh peristiwa pada zaman itu. Karena

39 Sheingold, 1973 dalam Handbook of political communication research / edited by Lynda Lee Kaid, hlm 5 
Negara-negara yang berperang menggunakan propaganda, studi komunikasi politik juga berkutat pada masalah propaganda. Lalu era tekonologi yang cepat menyebabkan persaingan di dunia politik dan rentannya potensi konflik baik secara internal dan eksternal, maka muncullah dunia professional baru seperti adanya Publik Relation politik, marketing politik dan menjamurnya lembaga pooling dan survei politik seperti pengukuran tingkat elaktabilitas partai atau calon kandidat. Publik Relation atau disebut humas digunakan oleh para politisi, partai politik dan juga pemerintah. Terutama pada saat kampanye pemilu oleh para kandidat calon legislatif dan juga partai politik.

Tahun 2016 pemerintahan presiden Jokowi memperkerjakan Humas Pemerintahan yang berjumlah 100 orang yang disebar di beberapa departemen dan kementrian. Humas pemerintahan di pimpin oleh seorang Juru bicara kepresidenan, hal ini untuk menciptakan satu narasi atau satu pintu komunikasi pemerintahan yang ditunjuk yaitu Johan Budi mantan wakil ketua dan juru bicara KPK. Ini adalah suatu ikhitar dari berbagai peristiwa buruknya pengelolaan komunikasi pemerintahan seperti tidak kompak atau sinkronnya informasi yang dikeluarkan oleh kepala negara dengan mentri-mentrinya, atau antara mentri yang satu dengan lainnya tidak ada kolerasi. Kondisi seperti ini sangat mudah ditebak oleh logika publik yang sederhana bahwa terjadi ketidak harmonisan di internal pemerintah dan kabinetnya. Mengingatkan kita bahwa dulu di era Orde Baru semua informasi ada pada satu pintu yaitu dilakukan oleh Mentri Penerangan, sehingga sering kita menonton di layar kaca bagaimana Harmoko selalu tampil dalam konfrensi press untuk menjelaskan (output) dari kebijakan pemerintah saat itu.

Komunikasi politik kekinian dapat juga kita lihat dari penggunaan media yang dipakai. Media komunikasi politik dapat dibagi menjadi lima jenis tergantung pada bagaimana komunikasi mengalir melalui media tersebut seperti model dibawah ini:
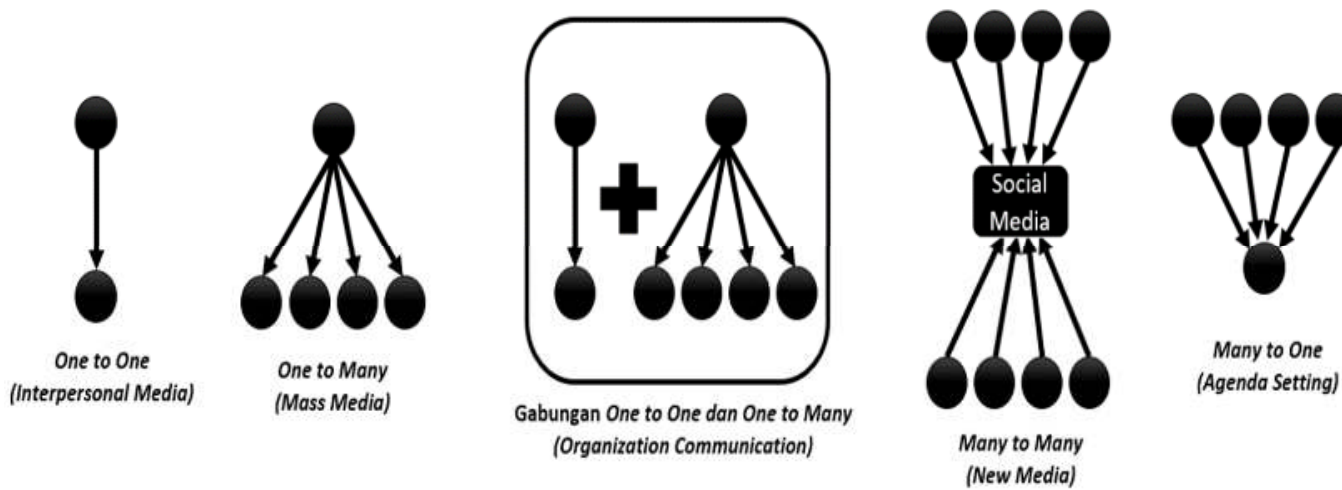

(Agenda Setting)

Gambar 1.4: Model pola-pola media Komunikasi Politik 
Penjelasan mengenai model-model tersebut merupakan dinamika yang terjadi dalam proses komunikasi politik di era digital. Dengan adanya ruang publik di media sosial antara tokoh politik, masyarakat, media massa bisa berinteraksi dari tahap komunikasi linear, sirkular dan intraksional terjadi melalui jalur media baru. Selanjutnya dibawah ini adalah penjelasan dari model saluran media tersebut diatas.

Tabel 1.5: Penggunaan Media (saluran) dalam Komunikasi Politik

\begin{tabular}{|c|c|c|}
\hline 1. & $\begin{array}{l}\text { One to One } \\
\text { (Interpersonal } \\
\text { Media) }\end{array}$ & $\begin{array}{l}\text { - Dengan satu arah atau dua arah komunikasi, komunikasi tatap } \\
\text { muka, lalu menggunakan perantara tokoh (pemuka masyarakat) } \\
\text { atau Opinion Leader yang akhirnya diteruskan ke jaringan bawahan } \\
\text { (masyarakat) dimana peran pengaruh dan kekuasaannya digunakan } \\
\text { (two flow step communication). } \\
\text { - Dengan mendatangi langsung masyarakat (khalayak) dengan } \\
\text { memangkas prosedural birokrasi. Bisa dikatakan dengan istilah } \\
\text { kunjungan sampel (diambil dibeberapa tempat yang menjadi } \\
\text { perwakilan dari populasi), ini bisa disebut dengan istilah "Turba" } \\
\text { yang artinya turun kebawah atau dengan istilah "blusukan". } \\
\text { - Termasuk dengan penggunaan surat pribadi, telepon pribadi, dan } \\
\text { saluran lain untuk melakukan korespodensi dan pembicaraan, } \\
\text { seperti SMS, PO BOX, dan sebagainya. }\end{array}$ \\
\hline 2. & $\begin{array}{l}\text { One to Many } \\
\text { (Mass Media) }\end{array}$ & $\begin{array}{l}\text { - Bentuk pertama, yaitu secara langsung, seperti kandidat politik } \\
\text { berbicara di depan rapat umum atau seperti seorang presiden } \\
\text { muncul di depan khalayak besar reporter dalam konfrensi pers. } \\
\text { - Bentuk kedua, terjadi jika ada perantara ditempatkan antara } \\
\text { komunikator dan khalayak. Akan terjadi satu arah, media, } \\
\text { teknologi, sarana, dan alat komunikasi lainnya (buku, Surat kabar } \\
\text { cetak, Televisi atau Radio). Contoh pidato kepresidenan yang } \\
\text { disiarkan ke seluruh dunia melalui televisi. }\end{array}$ \\
\hline 3. & $\begin{array}{l}\text { Gabungan One } \\
\text { to One dan One } \\
\text { to Many } \\
\text { (Organization } \\
\text { Communication) }\end{array}$ & $\begin{array}{l}\text { - Melakukan komunikasi atau diskusi antara pimpinan dan } \\
\text { bawahannya. Seperti seorang presiden kepada staf, penasehat dan } \\
\text { para mentri yang membawahi departemen. } \\
\text { - Karena organisasi politik itu besar maka untuk melakukan one to one } \\
\text { mustahil, maka dilakukan dengan sarana one to many, seperti: } \\
\text { pengedaran memorandum, melakukan sidang rutin tahunan, } \\
\text { bulletin, laporan berkala intern dan lokakarya. }\end{array}$ \\
\hline 4. & $\begin{array}{l}\text { Many to Many } \\
\text { (New Media) }\end{array}$ & $\begin{array}{l}\text { - Politisi, pejabat dan kandidat politik menggunakan jejaring } \\
\text { komunikasi (Network communication) ke banyak arah. } \\
\text { - Melalui media sosial banyak politisi atau kandidat politik memliki } \\
\text { akun Facebook, Twitter, youtube, blog atau situs pribadi yang } \\
\text { langsung dapat berinteraksi dengan khalayak banyak (netizen) } \\
\text { dengan meng-follow, meng-add akun pribadi komunikator tersebut } \\
\text { tersebut. } \\
\text { - Para komunikator politik bisa ditemui di dunia maya oleh netizen, } \\
\text { melakukan update status yang berisi gagasan, pandangan dan sikap } \\
\text { dengan me-mention langsung ke tujuan, termasuk melalukan } \\
\text { pembicaraan pribadi (chat-rooms), membuka website pribadi (social } \\
\text { media websites) dan juga pengguaan aplikasi smart phone seperti } \\
\text { Black Barry Massenger (BBM), Whatsup (WA), dan lain-lain, serta } \\
\text { penggunaan group-group atau komunitas di media sosial dan } \\
\text { applikasi untuk melakukan kordinasi, menyebarkan informasi } \\
\text { (broadcast), kadang media konvensional juga mengambil/ mengutip } \\
\text { status-status dari media sosial dan dipublikasikan dan sebagainya. }\end{array}$ \\
\hline
\end{tabular}




\begin{tabular}{|c|c|c|}
\hline 5. & $\begin{array}{l}\text { Many to One } \\
\text { (Agenda Setting) }\end{array}$ & $\begin{array}{l}\text { - Reputasi Politikus dimainkan oleh peran media massa dengan } \\
\text { meluasnya minat masyarakat (opini publik). } \\
\text { - Reputasi Politikus dinaikkan dan juga dijatuhkan (dikaburkan) } \\
\text { melalui lambng-lambang yang beredar di media massa. Isu bisa } \\
\text { sengaja dirancang (framing) atau dengan memanfaatkan momen } \\
\text { kondisi kekurangan atau masa lalu kandidat yang negatif dengan } \\
\text { melakukan agenda setting oleh media baik media tradisional } \\
\text { ataupun media baru yang terkenal dengan istilah "bullying". }\end{array}$ \\
\hline
\end{tabular}

Di era teknologi digital, interaksi antar aktor komunikasi politik tidak lagi dominan atas ke bawah namun juga bawah ke atas. Di zaman ini, partisipasi publik ikut berperan mengolah pesan-pesan politik. Media massa utama menjadi jembatan komunikasi, contohnya menyebarkan pesan-pesan dukungan kepada KPK di Facebook dengan nama Save KPK menjadi trending topic yang luas dan mendapat dukungan dan perhatian masyarakat baik secara nasional dan internasional. Hal ini ternyata dapat mempengaruhi sikap pemerintah pada kasus Bibit-Chandra sehingga dengan alasan pertimbangan kemanusiaan dan memperhatikan kondisi pendapat umum di masyarakat kasus yang dianggap kriminalisasi tersebut dihentikan.

\section{Daftar Pustaka}

Achmad, Mudlor. (tanpa tahun). Etika Dalam Islam. Surabaya: Al-ikhlas.

Adji, Oemar Seno. 1973. Mass Media dan Hukum. Jakarta: Erlangga.

Ahmad, Zainal Abidin. 1974. Negara Adil Makmur Menurut Ibnu Sina. Jakarta: Bulan Bintang.

Alfian. 1991. Komunikasi Politik dan Sistem Politik Indonesia. Jakarta: Gramedia Pustaka Utama.

Al-Ghazali, Imam. 1995. Ringkasan Ihya Ulumuddin. Jakarta: Pustaka Amani.

Almond, Gabriel dan James S. Coleman [Eds.]. 1960. The Politics of the Developing Areas. Princeton University Press.

Almond, Gabriel dan Sidney Verba. 1990. Budaya Politik: Tingkah Laku Politik dan Demokrasi di Lima Negara. Jakarta: Bumi Aksara.

Alonso, Sonia. 2011. The Future of Representative Democracy. Cambridge University Press.

Arifin, Anwar. 1992. Komunikasi Politik dan Pers Pancasila. Jakarta: Media Sejahtera.

2011. Komunikasi Politik: Filsafat, Paradigma, Teori, Tujuan, Strategi dan Komunikasi Politik Indonesia. Yogyakarta: Graha Ilmu. 
Bahm, Archie J. 2003. Filsafat Perbandingan: Filsafat Barat, India, Cina dalam Perbandingan. Yogyakarta: Kanisius.

Bambang S. dan Sugianto. 2007. Pendidikan Kewarganegaraan. Surakarta: Penerbit Grahadi.

Barker, Ernest. 1962. The Politics of Aristotle. Oxford University Press.

Bastian, Indra. 2007. Akuntansi untuk LSM dan Partai Politik. Jakarta: Erlangga.

Benedict, Ruth. 2006. Patterns of Culture. Mariner Books.

Berg-Schlosser, Dirk dan Ralf Rytlewski [Eds.]. 1993. Political Culture in Germany. Palgrave Macmillan.

Bertalanffy, Ludwig Von. 2003. General System Theory: Foundations, Development, Applications. George Braziller Inc.

Bertens, K. 2000. Etika. Jakarta: Gramedia Pustaka Utama.

Blake, Reed H. dan Edwin O. Haroldsen. 2003. Taksonomi Konsep Komunikasi. Terjemahan oleh Hasan Bahanan. Surabaya: Papyrus.

Budiardjo, Miriam. 2008. Dasar-dasar Ilmu Politik. Jakarta: Gramedia Pustaka Utama.

Cangara, Hafied. 2011. Komunikasi Politik: Konsep, Teori dan Strategi. Jakarta: RajaGrafindo Persada.

Chilcote, Ronald H. 1981. Theories of Comparative Political Economy. Westview Press.

Dahl, Robert A. dan Bruce. 2002. Modern Political Analysis. Pearson.

DeVito, Joseph A. 2011. Komunikasi Antarmanusia. Karisma Publishing.

Diamond, Larry. 2003. Dinamika Konsolidasi Demokrasi. Yogyakarta: IRE Press.

Djafar, Massa. 2015. Krisis Politik \& Proposisi Demokratisasi. Jakarta: Bumi Aksara.

Dovring, Karin. 1987. Harold Dwight Lasswell: His Communication With a Future. K. Dovring.

Easton. David. 1965. A Framework for Political Analysis. Prentice-Hall, Inc. 1965. Systems Analysis of Political Life. John Wiley \& Sons Ltd.

Erikson, Robert dan Kent L. Tedin. 2014. American Public Opinion: Its Origins, Content and Impact. Routledge.

Fagen, Richard R. 1966. Politics and Communication: An Analytic Study. Little Brown \& Company.

Faturohman, Deden dan Wawan Sobari. 2002. Pengantar Ilmu Politik. Malang: UMM Press.

Ferrari, G.R.F. 2005. City and Soul in Plato's Republic. The University of Chicago Press.

Han, Sam dan Kamaludeen Mohamed Nasir. 2015. Digital Culture and Religion in Asia. Routledge.

Hastuti, Sri [Ed.]. 2011. New Media: Teori dan Aplikasi. Surakarta: Lindu Pustaka. 
Heryanto, Gun Gun dan Irwa Zarkasy. 2011. Public Relations Politik. Jakarta: Ghalia Indonesia.

Hikmat, Mahi M. 2010. Komunikasi Politik: Teori dan Praktik (Dalam Pilkada Langsung). Bandung: Simbiosa Rekatama Media.

Husaini, Adian. 2002. Penyesatan Opini: Sebuah Rekayasa Mengubah Citra. Jakarta: Gema Insani Press.

Jefkins, Frank. 2004. Public Relations (Edisi 5). Jakarta: Erlangga.

Johari, Jagdish Chandra. 1972. Comparative Politics. Sterling Publishers.

Kaid, Lynda Lee (Ed.). 2004. Handbook of Political Communication Research. Routledge.

Kantaprawira, Rusadi. 2006. Sistem Politik Indonesia: Suatu Model Pengantar. Bandung: Sinar Baru Algensindo.

Klosko, George. 2012. History of Political Theory: An Introduction: Volume I: Ancient and Medieval. Oxford University Press.

Langeveld, M.J. 1959. Menuju ke Pemikiran Filsafat. Jakarta: PT. Pembangunan.

Lasswell, Harold D. 1936. Politics: Who Gets What, When, How. Peter Smith Pub Inc.

Lasswell, Harold D. dan Abraham Kaplan. 2013. Power and Society: A Framework for Political Inquiry. Transaction Publishers.

Lippmann, Walter. 1998. Opini Umum. Jakarta: Yayasan Obor Indonesia.

Magnis-Suseno, Franz. 1992. Filsafat Sebagai Ilmu Kritis. Yogyakarta: Kanisius. 1993. Etika Dasar: Masalah-masalah Pokok Filsafat Moral. Yogyakarta: Kanisius.

Makmurtono, Agus dan Munawir. 1989. Etika (Filsafat Moral). Jakarta: Wira Sari.

Manheim, Karl. 1987. Sosiologi Sistematis: Suatu Pengantar Studi Tentang Masyarakat. Jakarta: Bina Aksara.

Masdar, Umaruddin [et al.]. 1999. Mengasah Naluri Publik Memahami Nalar Politik. Yogyakarta; LKiS.

McNair, Brian. 2003. An Introduction to Political Communication (Communication and Society). Routledge.

Mulyana, Deddy. 2013. Komunikasi Politik, Politik Komunikasi: Membedah Visi Dan Gaya Komunikasi Praktisi Politik. Bandung: Remaja Rosdakarya.

Nasuka. 2005. Teori Sistem Sebagai Salah Satu Alternatif Pendekatan dalam Ilmu-Ilmu Agama Islam. Jakarta: Kencana.

Nasution, Zulkarimien. 1990. Komunikasi Politik: Suatu Pengantar. Jakarta: Ghalia Indonesia.

Nimmo, Dan. 2001. Komunikasi Politik: Khalayak dan Efek. Bandung: Remaja Rosdakarya.

2006. Komunikasi Politik: Komunikator, Pesan dan Media. Terjemahan oleh Jalaluddin Rakhmat. Bandung: Remaja Rosdakarya. 
Nurdin, Muslim [et al.]. 1995. Moral dan Kognisi Islam. Bandung: CV. Alfabeta.

Nurudin. 2001. Komunikasi Propaganda. Bandung: Remaja Rosdakarya.

Olii, Helena. 2007. Opini Publik. Jakarta: PT. Indeks.

Pasiak, Taufiq. 2004. Revolusi IQ/EQ/SQ: Menyingkap Rahasia Kecerdasan Berdasarkan Quran dan Teori Neurosains Mutakhir. Bandung: PT. Mizan Publika.

Patterson, Kerry dan Joseph Grenny. 2005. Crucial Conversations - Strategi Menghadapi Percakapan Berisiko Tinggi. Jakarta: Gramedia Pustaka Utama.

Peter, Laurence J. 1986. Piramida Peter: atau Mungkinkah kita Mencapai Puncaknya. Jakarta: Erlangga.

Plano, Jack C., Robert E. Riggs dan Helena S. Robin. 1989. Kamus Analisa Politik. Jakarta: Rajawali.

Purwasito, Andrik. 2011. Pengantar Studi Politik. Surakarta: UNS Press.

R. G. Meadow. 1985. Political Communication Research in the 1980s. Journal of Communication. Volume 35 Issue 1.

Ranney, Austin. 1992. Governing: An Introduction to Political Science. Prentice Hall College.

Rauf, Maswadi dan Mappa Nasrun [Eds.]. 1993. Indonesia dan Komunikasi Politik. Jakarta: Gramedia Pustaka Utama.

Reksosusilo, Stanislaus. 2005. Diktat Kuliah Filsafat Cina. Malang: STFT Widya Sasana.

Rogers, Everett M. 2004. 'Theoritical Diversity in Political Communication'. In Lynda Lee Kaid (Ed.), Handbook Handbook of Political Communication Research. Routledge.

Rosenthal, Erwin Isak Jakob. 2009. Political Thought in Medieval Islam: An Introductory Outline. Cambridge University Press.

Ruck, Anne. 2008. Sejarah Gereja Asia. Jakarta: BPK Gunung Mulia.

Ruslan, Rosady. 2005. Kiat dan Strategi Kampanye Public Relations. Jakarta: RajaGrafindo Persada.

Sanit. Arbi. 2002. Politik, Demokrasi dan Manajemen Komunikasi. Yogyakarta: Galang Press.

Sastropoetro, Santoso. 1990. Komunikasi Sosial. Bandung: Remaja Rosdakarya.

Shahreza, Mirza. 2017. Komunikator Politik Berdasarkan Teori Generasi. Journal of Communication (Nyimak), Vol. 1, No. 1, 33-48.

Shahreza, Mirza dan Korry El-Yana. 2016. Etika Komunikasi Politik. Tangerang: Indigomedia.

Sobur, Alex. 2001. Etika Pers Profesionalisme dengan Nurani. Bandung : Humaniora Utama Press.

Soemarno dan Rochajat Harun. 2006. Komunikasi Politik: Sebagai Suatu Pengantar. Bandung: Mandar Maju. 
Soemarno. 1989. Dimensi-Dimensi Komunikasi Politik. Bandung: Citra Aditya Bakti. 2009. Materi Pokok Komunikasi Politik. Jakarta: Universitas Terbuka.

Soemirat, Soleh dan Elvinaro Ardianto. 2007. Dasar-Dasar Public Relations. Bandung: Remaja Rosdakarya.

Strauss, William dan Neil Howe. 1991. Generations: The History of America's Future, 1584 to 2069. William Morrow \& Co. 1993. 13th Gen: Abort, Retry, Ignore, Fail? Vintage. . 2000. Millennials Rising: The Next Great Generation. Vintage.

Suhandang, Kustadi. 2004. Pengantar Jurnalistik: Seputar Organisasi, Produk dan Kode Etik. Bandung: Nuansa Cendekia.

Suito, Deny. 2006. Membangun Masyarakat Madani. Jakarta: Centre For Moderate Muslim Indonesia.

Surbakti, Ramlan. 1992. Memahami Ilmu Politik. Jakarta: Grasindo.

Susanto, Astrid, S. 1985. Komunikasi Sosial di Indonesia. Bandung: Binacipta.

Suwardi, Arsono [et al.]. 2002. Politik, Demokrasi \& Manajemen Komunikasi. Yogyakarta: Galang Press.

Syah, Sirikit. 2014. Membincang Pers: Kepala Negara dan Etika Media. Jakarta: Elex Media Komputindo.

Tabroni, Roni. 2012. Komunikasi Politik Pada Era Multimedia. Bandung: Simbiosa Rekatama.

Tamburaka, Apriadi. 2013. Literasi Media: Cerdas Bermedia Khalayak Media Massa. Jakarta: Rajawali Pers.

Thompson, George Carslake. 2012. Public Opinion and Lord Beaconsfield (Volume 1). Ulan Press.

Tocqueville, Alexis de. 1990. Democracy in America, Volume 1. Vintage.

Tubbs, Stewart L. dan Sylvia Moss. 2001. Human Communication: Konteks-Konteks Komunikasi (Buku 1). Bandung: Remaja Rosdakarya.

Umary, Barnawie. 1993. Materia Akhlak. Solo: Ramadhani.

Varma, SP. 1995. Teori Politik Modern. Jakarta: RajaGrafindo Persada.

Weber, Max [et al.]. 1947. The Theory of Social and Economic Organization. Oxford University Press.

West, Richard dan Lynn H. Turner. 2008. Pengantar Teori Komunikasi: Analisis dan Aplikasi (Buku 1). Jakarta: Salemba Humanika.

Wibowo, Eddi [et al.]. 2004. Ilmu Politik Kontemporer. Yogyakarta: YPAPI.

Wiseman, H. Victor. 1966. Political Systems : Some Sociological Approaches. Praeger.

Young, Oran R. 1968. Systems of Political Science (Foundations of Modern Political Science Series). Prentice-Hall. 
Yu-Lan, Fung. 2007. Sejarah Filsafat Cina. Yogyakarta: Pustaka Pelajar. 